In cooperation with the Texas Parks and Wildlife Department and the University of Texas Bureau of Economic Geology

\title{
Indications and Potential Sources of Change in Sand Transport in the Brazos River, Texas
}

Water-Resources Investigations Report 01-4057

U.S. Department of the Interior

U.S. Geological Survey 
U.S. Department of the Interior

U.S. Geological Survey

\section{Indications and Potential Sources of Change in Sand Transport in the Brazos River, Texas}

By David D. Dunn and Timothy H. Raines

\section{U.S. GEOLOGICAL SURVEY}

Water-Resources Investigations Report 01-4057

In cooperation with the Texas Parks and Wildlife Department and the University of Texas Bureau of Economic Geology 


\section{U.S. DEPARTMENT OF THE INTERIOR}

Gale A. Norton, Secretary

\section{U.S. GEOLOGICAL SURVEY}

Charles G. Groat, Director

Any use of trade, product, or firm names is for descriptive purposes only and does not imply endorsement by the U.S. Government.

For additional information write to

\section{District Chief}

U.S. Geological Survey

8027 Exchange Dr.

Austin, TX 78754-4733

E-mail: dc_tx@usgs.gov

Copies of this report can be purchased from

U.S. Geological Survey

Branch of Information Services

Box 25286

Denver, CO 80225-0286

E-mail: infoservices@usgs.gov 


\section{CONTENTS}

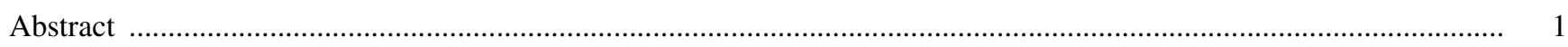

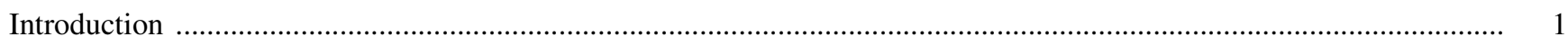

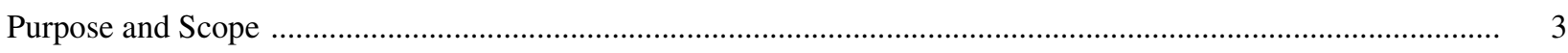

Description of the Brazos River Basin . .............................................................................................. 3

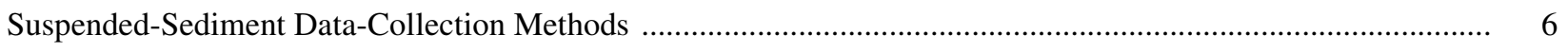

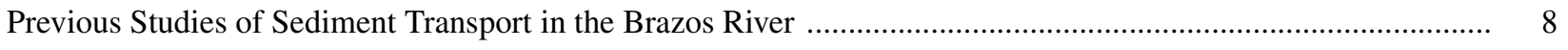

Capacity of the Brazos River to Transport Sand .................................................................................... 9

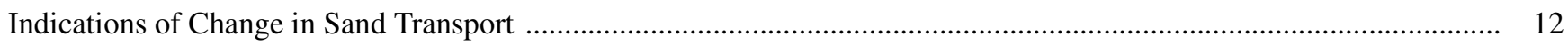

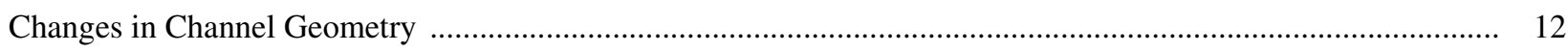

Changes in Suspended-Sediment Characteristics ................................................................................... 15

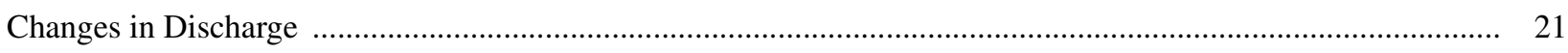

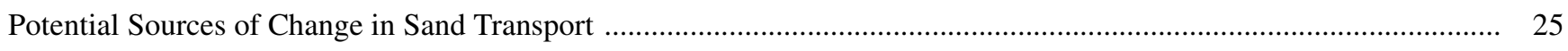

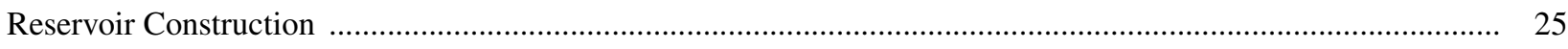

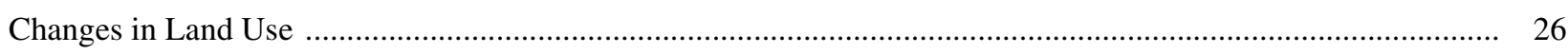

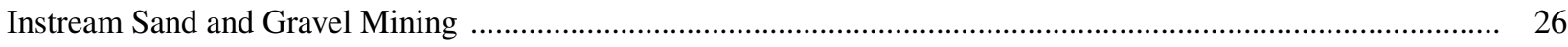

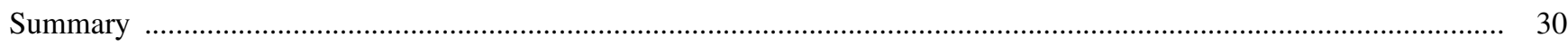

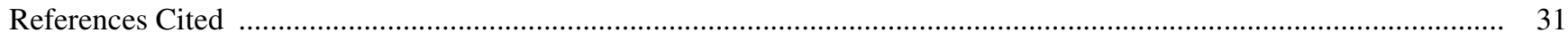

\section{FIGURES}

1. Map showing Texas Gulf of Mexico shoreline ………......................................................................... 2

2. Map showing Brazos River Basin, Texas ............................................................................................. 3

3. Photograph showing typical cut bank on the Brazos River, Texas ................................................................. 4

4. Map showing location of selected streamflow-gaging stations in the lower Brazos River Basin, Texas ............ 5

5-7. Graphs showing:

5. Historical development of reservoir conservation storage capacity in the Brazos River Basin,

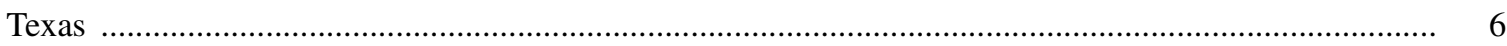

6. Particle-size distributions of bed material samples near streamflow-gaging station 08114000 Brazos River at Richmond, Texas ........................................................................................ 10

7. Flow-duration curve of daily mean discharge for streamflow-gaging station 08114000 Brazos River at Richmond, Texas, 1903-95 (excluding 1907-21)

8-10. Graphs showing stage-discharge relation at streamflow-gaging station:

8. 08111500 Brazos River near Hempstead, Texas .......................................................................... 13

9. 08114000 Brazos River at Richmond, Texas ................................................................................. 14

10. 08116650 Brazos River near Rosharon, Texas ................................................................................ 14

11-13. Graphs showing water-surface altitudes at a discharge of 5,000 cubic feet per second at streamflowgaging station:

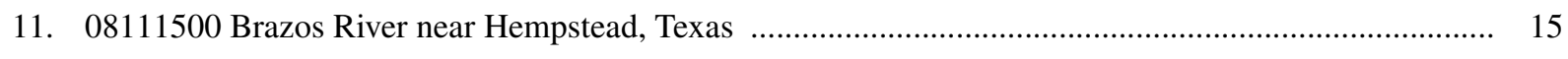

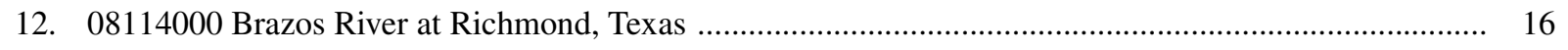

13. 08116650 Brazos River near Rosharon, Texas ............................................................................... 16 
14-18. Graphs showing:

14. Suspended-sand concentrations in samples at streamflow-gaging station 08114000 Brazos River at Richmond, Texas, 1969-95

15. Sampled discharges at streamflow-gaging station 08114000 Brazos River at Richmond, Texas, 1969-95

16. Relation of suspended-sand concentration to discharge at streamflow-gaging station 08114000 Brazos River at Richmond, Texas, 1969-95

17. Relation of percent sand in suspended-sediment samples to discharge at streamflow-gaging station 08114000 Brazos River at Richmond, Texas, 1969-95

18. Relation of mean channel velocity to discharge at streamflow-gaging station 08114000 Brazos River at Richmond, Texas, 1969-95

19-20. Graphs showing flow-duration curves of daily mean discharge for streamflow-gaging station:

19. 08111500 Brazos River near Hempstead, Texas, 1940-68 and 1969-95

20. 08114000 Brazos River at Richmond, Texas, pre-1940, 1940-68, and 1969-95

21-23. Graphs showing:

21. Suspended-sand transport curve for streamflow-gaging station 08114000 Brazos River at Richmond, Texas

22. Annual suspended-sand loads at streamflow-gaging station 08114000 Brazos River at Richmond, Texas

23. Total acres harvested in the 27 counties in the lower Brazos River Basin, Texas

24. Map showing location of selected sand and gravel production sites in the lower Brazos River Basin, Texas

25-26. Graphs showing:

25. Total annual weight of sand extracted and annual loads of suspended sand transported in the Brazos River between Hempstead and Rosharon, Texas, 1979-95

26. Cumulative annual weight of sand extracted and annual loads of suspended sand transported in the Brazos River between Hempstead and Rosharon, Texas, 1979-95

\section{TABLES}

1. Selected characteristics of streamflow-gaging stations on the main stem of the lower Brazos River, Texas 5

2. Selected characteristics of the 13 largest reservoirs in the Brazos River Basin, Texas

3. Ratios of shear stress to critical shear stress required for initiation of motion at streamflow-gaging station 08114000 Brazos River at Richmond, Texas

4. Summary of statistical tests for differences in annually computed daily flow percentiles between the pre-1940 period and the 1969-95 period at streamflow-gaging station 08114000 Brazos River at Richmond, Texas 


\title{
Indications and Potential Sources of Change in Sand Transport in the Brazos River, Texas
}

\author{
By David D. Dunn and Timothy H. Raines
}

\section{Abstract}

Changes in the capacity of the Brazos River to transport sand can be identified within the context of Lane's relation through changes in channel geometry, changes in the characteristics of suspended loads, and changes in discharge. The Brazos River channel has been undergoing continual adjustment since the 1940s. For a discharge of 5,000 cubic feet per second, the watersurface altitude has decreased 2 to 4 feet at the Hempstead and Richmond streamflow-gaging stations between 1940 and 1995. The characteristics of suspended-sediment samples at the Richmond streamflow-gaging station have changed between the periods 1969-81 and 198295. The amount of sand-size sediment transported in suspension has decreased. The distribution of both daily and annual-peak discharges has changed. However, the computed annual loads of suspended sand indicate no statistically significant change in the median annual load.

The transport of sand in the Brazos River depends on a complex set of factors, most of which are continually changing. Potential sources of change in sand transport in the Brazos River include the effects of reservoir construction, changes in land use, and instream sand and gravel mining. Extensive reservoir construction in the Brazos River Basin has reduced sand transport by trapping sediment and by reducing the magnitude of peak discharges. However, reductions in sand transport associated with reservoir construction apparently are compensated for by increases associated with tributary sediment inflow and localized bank erosion. The total area of harvested acres of non-hay crops in the lower Brazos River Basin during 1924-92 decreased more than 75 percent from about 32 percent to about 8 percent of the total area. Correspondingly, erosion potential has decreased substantially. Several sand and gravel mining sites are located on the Brazos River between Hempstead and Rosharon. The quantity of sediment extracted by instream sand and gravel mining operations could represent from 11 to 25 percent of the total sand transported by the Brazos River. The effects of mining on sand transport could not be quantified.

\section{INTRODUCTION}

The sand that constitutes much of the Texas shoreline along the Gulf of Mexico (fig. 1) is in continual motion. Tides, storm surges, wave action, wind, river processes, and longshore (littoral) drift act upon the sand and transport it along the shoreline to form and erode beaches, barrier islands, and peninsulas. Some of the sand supplied to this process originates in upland areas and is transported to the Gulf of Mexico by rivers and streams. Most of these rivers and streams discharge into bays or estuaries, which eventually will fill with sediment. Three of the largest rivers in Texas, the Brazos River, the Colorado River, and the Rio Grande, have filled their respective estuaries and have propagated deltas seaward (McGowen and others, 1977).

Longshore drift transports sand from the river deltas to other locations along the coast. The longshore drift generally moves material in a southwesterly direction along the coast from Port Arthur to south of Corpus Christi. An opposing current moves material in a northerly direction from the Mexico coastline toward Corpus Christi. A zone of convergence, also called a zone of stagnation, occurs at a latitude of about 27 degrees north. The exact location varies with prevailing tidal and weather patterns. 


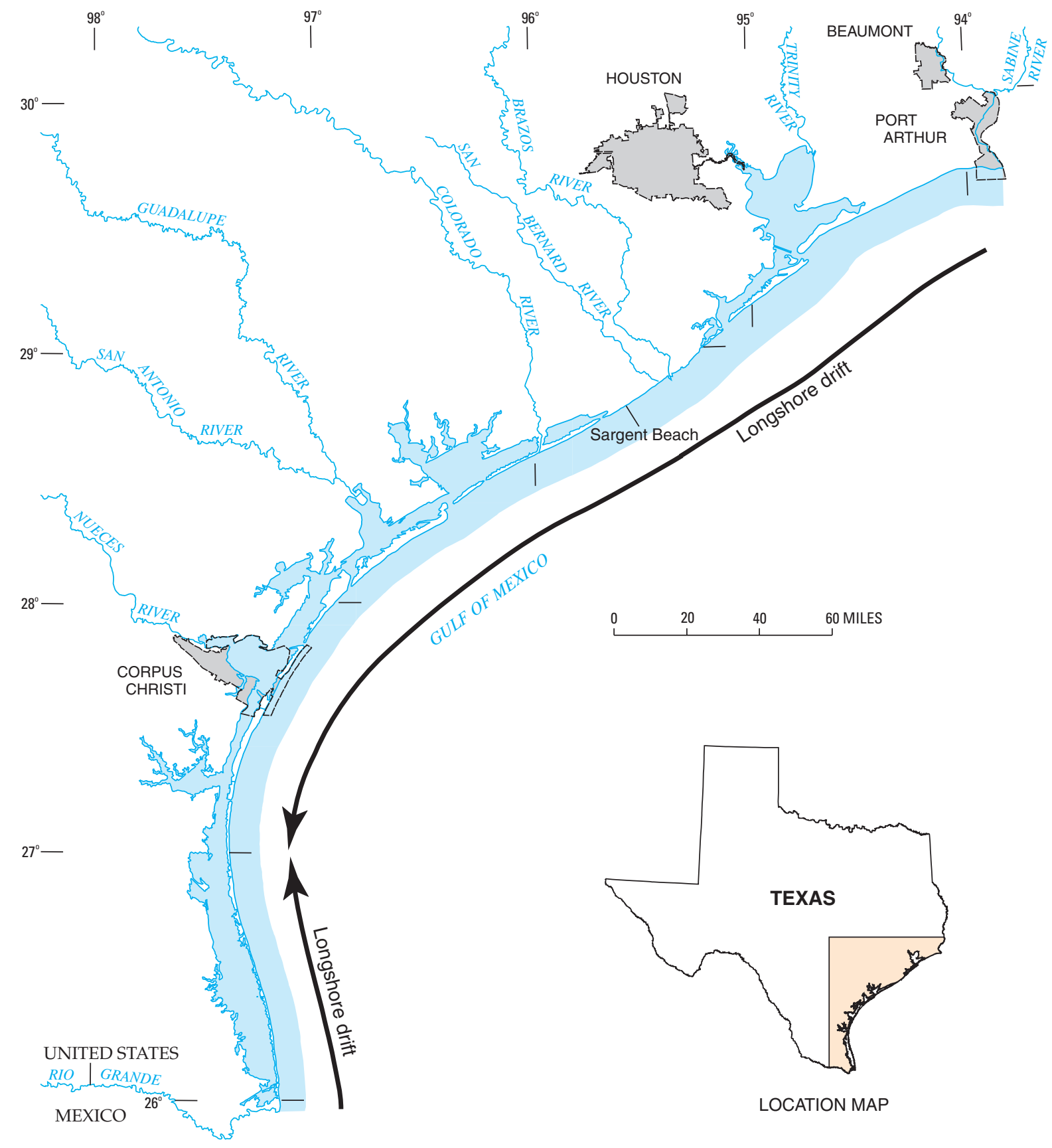

Figure 1. Texas Gulf of Mexico shoreline.

The Brazos River, Colorado River, Rio Grande, and the smaller San Bernard River are the only sources of additional sand supplied to the Texas Gulf beaches from outside the coastal system (McGowen and others, 1977). Sargent Beach, located south of the Brazos River mouth, has undergone more than 1,500 feet (ft) of inland erosion since the mid 1800s, or an average of about 12 feet per year (ft/yr). Short-term erosion rates of as much as $36 \mathrm{ft} / \mathrm{yr}$ have been documented by Morton and Pieper (1975) and Seelig and Sorenson (1973). Stauble and others (1994) state that Sargent Beach is eroding at a faster rate than any other Texas beach, and that the rate of erosion is due to a lack of sand-size material in the system. The lack of sand-size material in 


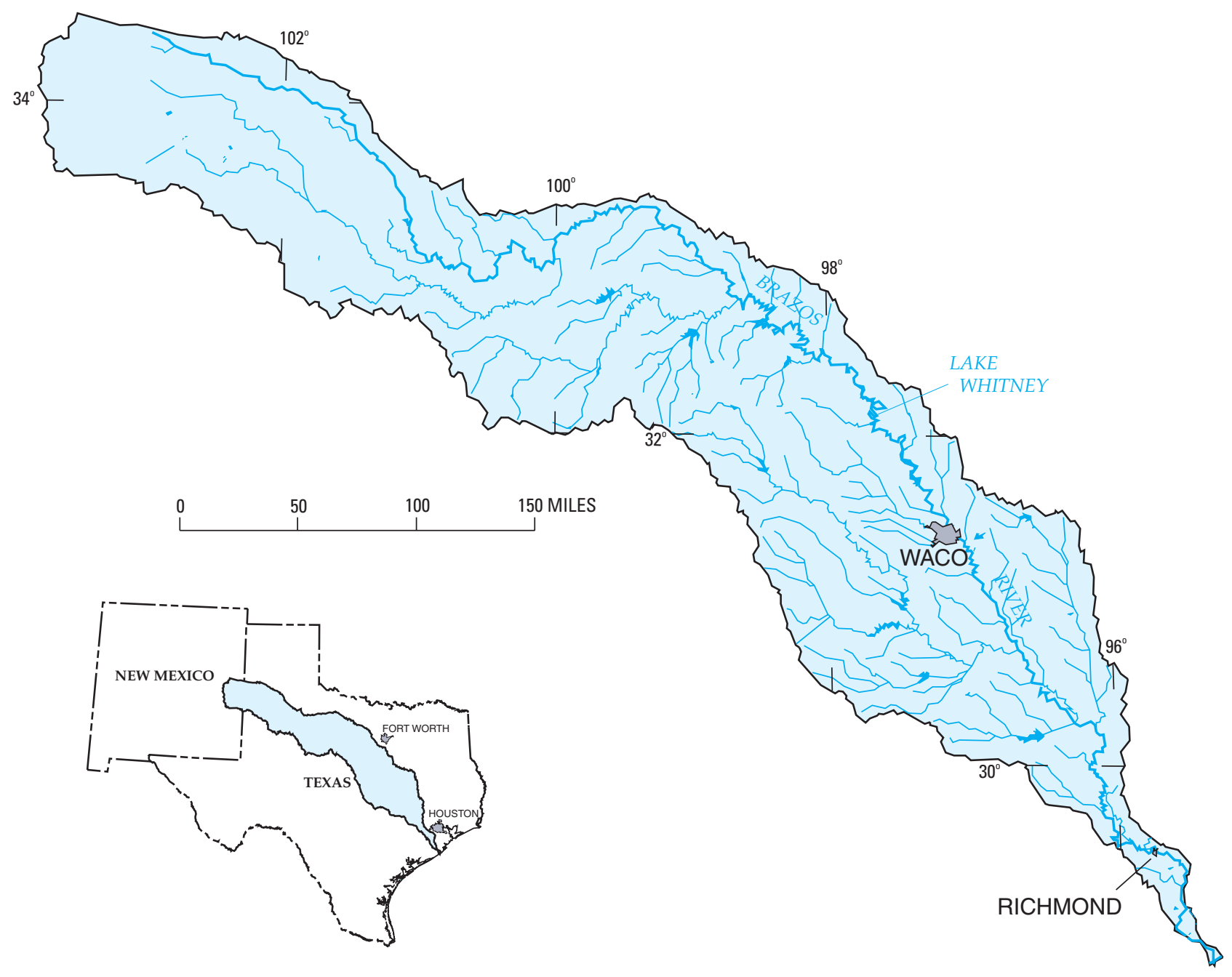

LOCATION MAP

Figure 2. Brazos River Basin, Texas.

the system has been attributed to a decreased supply of sand from the Brazos River by several researchers (Mathewson and Minter, 1976; Seelig and Sorenson, 1973; Stauble and others, 1994).

In 1995, the U.S. Geological Survey (USGS), in cooperation with the Texas Parks and Wildlife Department (TPWD) and the University of Texas Bureau of Economic Geology, began a study of sand transport in the Brazos River.

\section{Purpose and Scope}

This report describes the transport of sand-size sediment in the Brazos River and describes apparent changes in this sand transport with several indicators. The apparent changes are compared to potential causative sources, including reservoir construction, land-use changes, and instream sand and gravel mining. Sand-size sediment in this report refers to sediment particles having a sieve diameter larger than 0.062 millimeter ( $\mathrm{mm})$. Available stage, discharge, and suspended-sediment data collected at three Brazos River streamflow-gaging stations operated by the USGS, and bed-material data collected near Richmond, Tex., are analyzed for the period 1903-95 (excluding 1907-21).

\section{Description of the Brazos River Basin}

The Brazos River Basin (fig. 2) originates in eastern New Mexico and extends about 640 miles (mi) southeasterly across Texas to the Gulf of Mexico south 


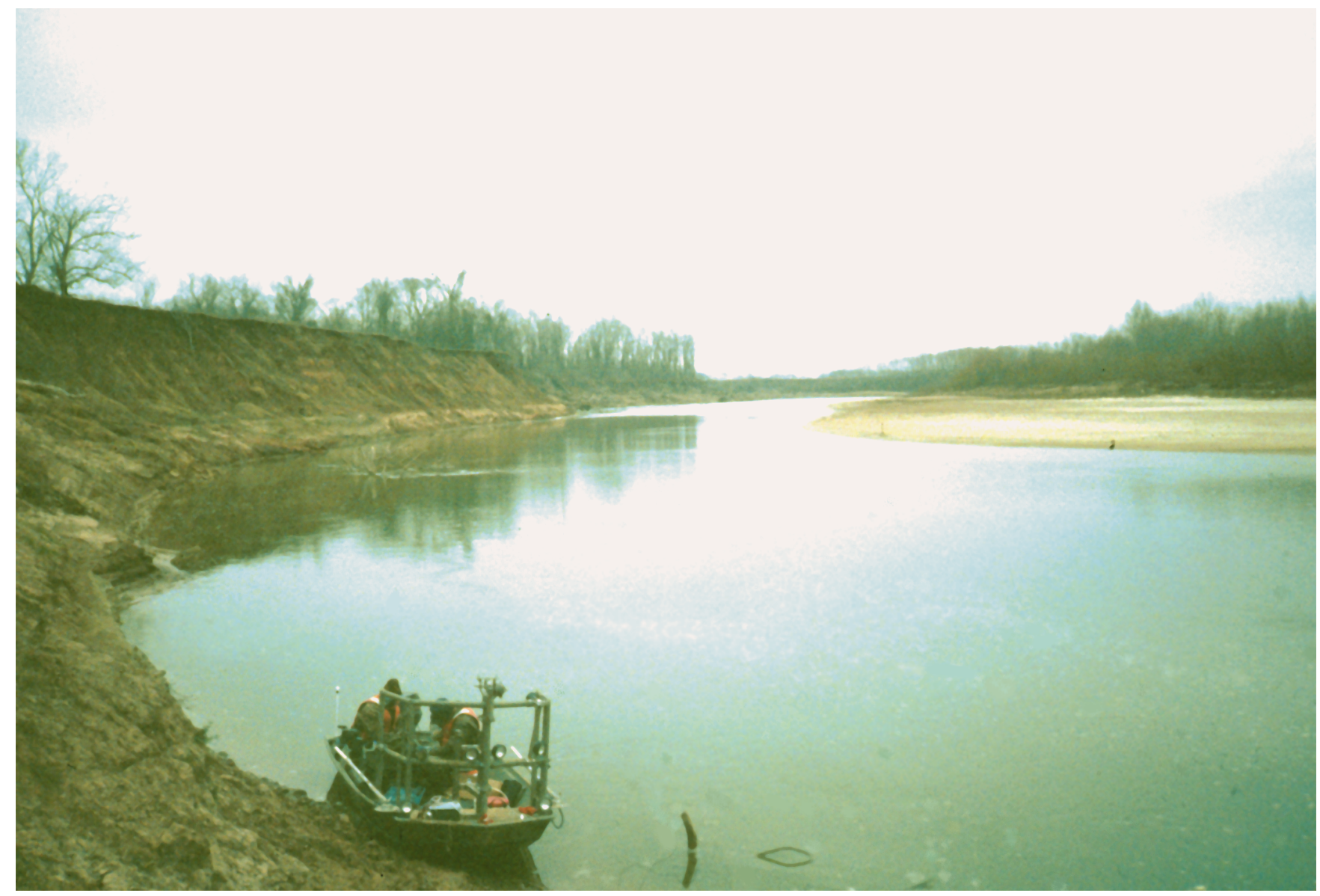

Figure 3. Typical cut bank on the Brazos River, Texas.

of Houston. The upper basin is about $70 \mathrm{mi}$ wide in the northwestern part of Texas, expands to a maximum width of 110 mi near Waco, and constricts to about 10 mi wide near Richmond in the lower basin. The Brazos River and its tributaries drain an area of about 45,600 square miles $\left(\mathrm{mi}^{2}\right)$. About $9,570 \mathrm{mi}^{2}$ of the upper part of the basin, including all of the area in New Mexico, does not contribute to downstream flows.

The Brazos River can be characterized as an incised, meandering, sand-bed channel with unstable banks. Frequent, near-vertical cut banks 20 to $35 \mathrm{ft}$ high are prominent along much of its length (fig. 3 ). In the lower 300 river miles of the Brazos River, the channel slopes 0.7 foot per mile (ft/mi). At streamflow-gaging station 08114000 Brazos River at Richmond, Tex., the channel is about $300 \mathrm{ft}$ wide and the median daily discharge is 3,000 cubic feet per second $\left(\mathrm{ft}^{3} / \mathrm{s}\right)$.

The USGS operates several streamflow-gaging stations on the main stem of the Brazos River. Three of these stations are located in the lower reach of the river downstream from the 13 largest reservoirs: 08111500 Brazos River near Hempstead, Tex.; 08114000 Brazos River near Richmond, Tex.; and 08116650 Brazos River near Rosharon, Tex. (fig. 4).

There is very little difference in drainage area between the three stations (table 1) because the basin narrows substantially in its lower reaches. The Richmond streamflow-gaging station has been active the longest and can be used to characterize total flows from the basin. All discharges recorded at the gaging stations since about 1940 are affected substantially by reservoir regulation. The mean annual discharge at the Richmond streamflow-gaging station for the period $1941-95$ was $7,600 \mathrm{ft}^{3} / \mathrm{s}$.

Reservoir construction has taken place in the Brazos River Basin since the early 1900s. In 1986, 1,178 reservoirs in the Brazos River Basin were listed in the dam inventory maintained by the Texas Natural Resource Conservation Commission (Wurbs and others, 1988). Reservoirs listed in the inventory meet at 


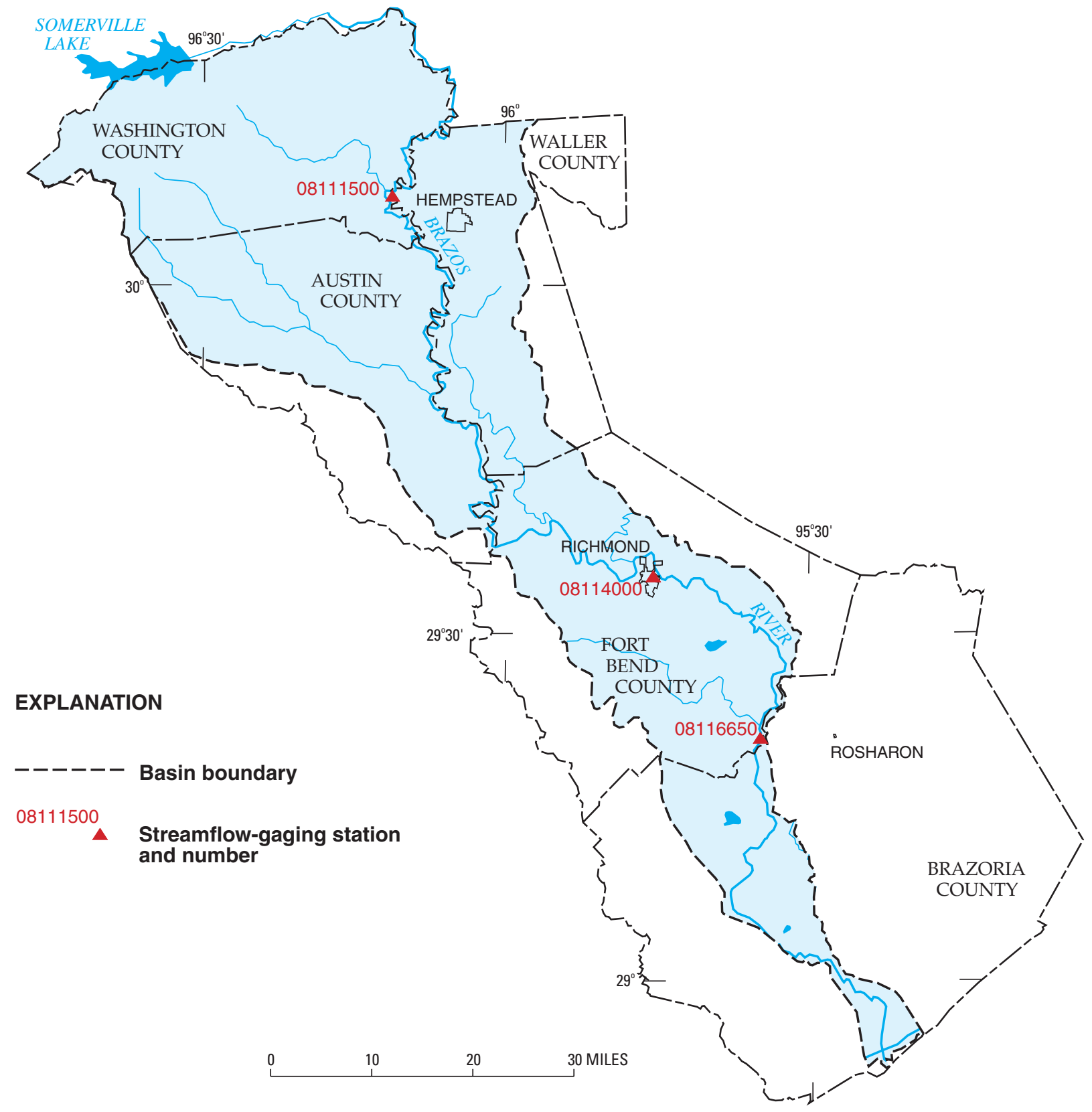

Figure 4. Selected streamflow-gaging stations in the lower Brazos River Basin, Texas.

Table 1. Selected characteristics of streamflow-gaging stations on the main stem of the lower Brazos River, Texas

\begin{tabular}{ccccc}
\hline $\begin{array}{c}\text { Station } \\
\text { number }\end{array}$ & Station name & $\begin{array}{c}\text { Drainage area } \\
\text { (square miles) }\end{array}$ & $\begin{array}{c}\text { Period of } \\
\text { record }\end{array}$ & $\begin{array}{c}\text { Mean annual discharge } \\
\text { (cubic feet per second) }\end{array}$ \\
\hline 08111500 & Brazos River at Hempstead, Texas & 43,880 & $1939-95$ & 6,900 \\
08114000 & Brazos River at Richmond, Texas & 45,007 & $1903-06$ & 17,600 \\
& & & $1922-95$ & \\
08116650 & Brazos River at Rosharon, Texas & 45,339 & $1967-95$ & 8,660 \\
\hline
\end{tabular}

${ }^{1}$ Computed for the period 1941-95. 


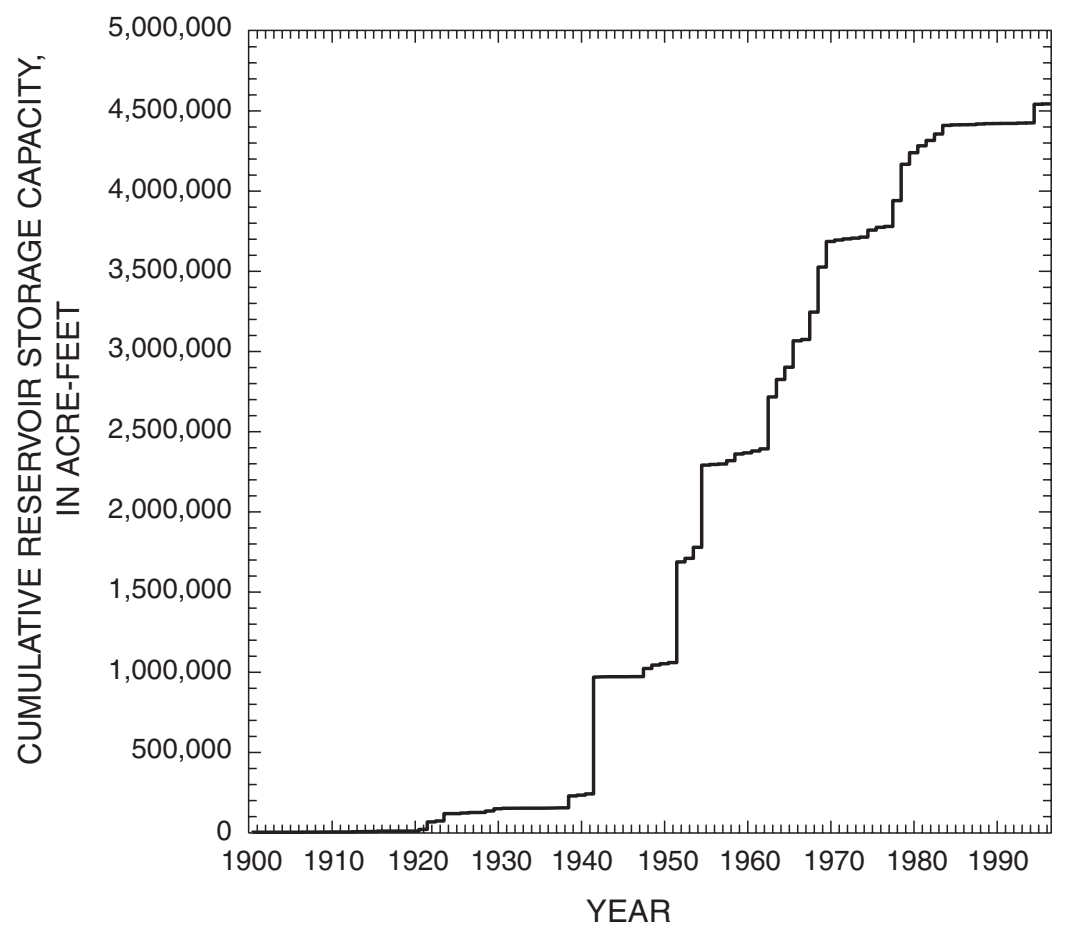

Figure 5. Historical development of reservoir conservation storage capacity in the Brazos River Basin, Texas (R.M. Slade, Jr., U.S. Geological Survey, written commun., 1999).

least one of the following two criteria: (1) storage capacity of 15 acre-feet (acre-ft) or greater and dam height of $25 \mathrm{ft}$ or greater or (2) storage capacity of 50 acre-ft or greater and dam height of $6 \mathrm{ft}$ or greater (Wurbs and others, 1988). Of 1,178 reservoirs, 13 contain 88 percent of the controlled storage in the Brazos River Basin. Nine of those 13 reservoirs are operated by the U.S. Army Corps of Engineers for flood control and contain all of the designated flood-control storage in the basin. Table 2 shows a summary of reservoir storage for the 13 largest reservoirs. Three of the reservoirs, including the largest, Lake Whitney, are located on the main stem of the Brazos River.

The rate of reservoir construction increased substantially during 1940-69 (fig. 5). Three periods can be identified: early (pre-1940), middle (1940-68), and late (1969-95). The early period reflects a time when relatively little reservoir construction occurred. The middle period reflects a time when reservoir conservation storage in the basin increased from 258,675 to $3,589,014$ acre-ft (more than 1,300 percent), and the late period reflects a time when reservoir conservation storage increased at a slower rate to $4,613,800$ acre-ft (about 29 percent).
Land use in the Brazos River Basin is predominantly agricultural and open rangeland. The dominant crops produced in the basin are cotton, corn, and sorghum (U.S. Department of Agriculture, 1997).

\section{Suspended-Sediment Data-Collection Methods}

The Texas Water Development Board (TWDB) and the USGS are the primary agencies that have collected sediment data from the Brazos River. The different sampling methods used by the agencies make the comparison of data difficult, particularly when analyzing the transport of sand-size particles. Only data collected by the USGS were analyzed in this study. The rationale for this decision is presented in the following discussion.

The TWDB has collected periodic suspendedsediment samples from streams in Texas, including the Brazos River, since the early 1900s. These data have been published in several compilation reports such as that by Dougherty (1979). The samples were collected using a device known as the "Texas sampler." The Texas sampler consists of a 15-inch (in.) hanger bar to which a sheet-metal bottle holder is fastened. Below the bottle 
Table 2. Selected characteristics of the 13 largest reservoirs in the Brazos River Basin, Texas (Wurbs and others, 1988)

\begin{tabular}{llcrrrr}
\hline \multicolumn{1}{c}{ Reservoir } & \multicolumn{1}{c}{$\begin{array}{c}\text { Stream } \\
\text { impounded }\end{array}$} & $\begin{array}{c}\text { Year of initial } \\
\text { impound- } \\
\text { ment }\end{array}$ & $\begin{array}{c}\text { Drainage } \\
\text { area } \\
\text { (square } \\
\text { miles) }\end{array}$ & $\begin{array}{c}\text { Conservation } \\
\text { pool }\end{array}$ & $\begin{array}{c}\text { Flood } \\
\text { control }\end{array}$ & Total \\
\hline Possum Kingdom Lake & Brazos River & 1941 & 23,596 & 570,240 & 154,460 & 724,700 \\
Lake Whitney & Brazos River & 1951 & 27,189 & 627,100 & $1,372,400$ & $1,999,500$ \\
Belton Lake & Leon River & 1954 & 3,531 & 457,600 & 633,720 & $1,091,320$ \\
Hubbard Creek Reservoir & Hubbard Creek & 1962 & 1,085 & $317,750$. & 198,050 & 515,800 \\
Proctor Lake & Leon River & 1963 & 1,259 & 59,400 & 314,800 & 374,200 \\
Lake Waco & Bosque River & 1965 & 1,652 & 152,500 & 573,900 & 726,400 \\
Somerville Lake & Yegua Creek & 1967 & 1,007 & 160,100 & 347,400 & 507,500 \\
Stillhouse Hollow Lake & Lampasas River & 1968 & 1,313 & 235,700 & 394,700 & 630,400 \\
Lake Granbury & Brazos River & 1969 & 25,679 & 153,490 & 87,150 & 240,640 \\
Lake Limestone & Navasota River & 1978 & 675 & 225,400 & 92,700 & 318,100 \\
Lake Georgetown & San Gabriel River & 1980 & 247 & 37,100 & 93,700 & 130,800 \\
Granger Lake & San Gabriel River & 1980 & 709 & 65,500 & 178,700 & 244,200 \\
Aquilla Reservoir & Aquilla Creek & 1983 & 252 & 52,400 & 93,600 & 146,000 \\
\hline
\end{tabular}

holder, a 15-pound current-meter weight is attached. An 8 -ounce small-mouth bottle is placed vertically in the bottle holder. The bottle is lowered about $1 \mathrm{ft}$ below the water surface and brought to the surface when air bubbles cease emanating from the bottle. The mean sediment concentration of the stream is computed as the average concentration of three samples taken at points one-fifth, one-half, and five-sixths of the distance across the river (Mathewson and Minter, 1976; Welborn, 1967), or from the concentration of a single sample taken at midstream (Dougherty, 1979).

The USGS has collected periodic and daily suspended-sediment data at the Brazos River at the Richmond gaging station since 1957 . These data were collected using depth-integrating samplers as described by Edwards and Glysson (1999) and developed through the Federal Interagency Sedimentation project. The depth-integrating samplers consist of a streamlined body with a nozzle that leads to a sample bottle placed inside the sampler body. An exhaust port releases air as it is replaced with the water-sediment mixture. Vanes on the sampler body orient the nose of the sampler into the current. The sampler is lowered from the water surface to the streambed and returned at a constant rate. The sampler continuously collects the water-sediment mixture over the entire vertical water column, except for the bottom $0.3 \mathrm{ft}$. The sampler nozzle and exhaust ports are designed so that samples are taken isokineticallythat is, the velocity of the water inside the sampler nozzle is the same as that of the surrounding water. This ensures that the sample is representative. Samples are obtained from multiple points across the stream by either the equal-width-increment (EWI) or the equaldischarge-increment (EDI) method (Edwards and Glysson, 1999). The mean sediment concentration of the stream is determined by the composite concentration of EWI samples or by discharge-weighting the concentrations of the individual EDI samples.

Suspended-sediment concentration varies with depth. Generally, silts and clays are uniformly distributed with depth, but the larger sand-size particles are present in greater concentration near the streambed because greater turbulence and shear stress are required to suspend them. For this reason, a sample collected near the water surface will not be representative of the entire water column and will consist primarily of wash load. In many instances, particularly when sand is not a substantial part of the sediment load, the mean concentration can be adjusted satisfactorily with a coefficient. The TWDB has recognized this and thus multiplies the 
mean sample concentration by a coefficient of 1.102 to estimate the mean concentration in the stream from the Texas sampler. Welborn (1967) compared paired sediment concentrations obtained using the two sampling methods and found the ratio of concentrations of suspended-sediment samples taken with depthintegrating samplers to samples taken with the Texas sampler ranged from 0.96 to 3.41. Welborn (1967) found that the ratio was largest in streams containing larger percentages of sand in the suspended load and that neither a single coefficient nor a set of coefficients could be computed to adjust data collected with the Texas sampler. The ratios for the Brazos River at Richmond ranged from 0.98 to 1.50 , and there is no relation between the coefficient and discharge.

Andrews (1989) presents mean monthly and annual suspended-sediment loads at the Brazos River at the Richmond gaging station for the 1966-86 water years (October 1-September 30). These loads were computed from daily suspended-sediment records collected by the USGS. The TWDB also operated a suspended-sediment sampling station at this location. Andrews (1989) compared 14 years of coincident data and found that mean annual loads computed from samples collected using the Texas sampler and depth-integrating samplers compared favorably. However, the loads computed by the USGS generally were larger than those computed by the TWDB. The difference in sampling methods used by the TWDB and the USGS could explain some of this difference. The USGS method is more likely to capture sand-size particles, which generally are found in greater concentration in the lower part of the water column than near the surface. This will tend to increase individual sample concentrations and, therefore, the loads computed using those concentrations.

Much of the analysis presented herein depends on analyses of individual sediment samples. Although the method used by the TWDB appears sufficient to compute total annual loads of suspended sediment (composed of both sand and silt sizes), the differences in data-collection methods become crucial when analyzing only the sand fraction of the suspended load.

\section{Previous Studies of Sediment Transport in the Brazos River}

Mathewson and Minter (1976) analyzed suspended-sediment data collected by the TWDB and streamflow data collected by the USGS to estimate the effect of water-resource development (reservoir construction) on coastal erosion in the vicinity of the Brazos River. They found from an analysis of daily mean discharges during 1923-74 that construction of both Possum Kingdom Lake (east of Fort Worth) and Lake Whitney has slightly reduced the frequency of larger discharges at the Richmond streamflow-gaging station, but the mean annual discharge at Richmond has not been affected by reservoir construction. They also found from an analysis of TWDB data for 1924-70 that suspended-sediment loads at Richmond have decreased substantially because of reduced concentrations of suspended sediment. Mathewson and Minter (1976) found that reduced sediment transported from the Brazos River to the Gulf can be attributed to increased storage of sediment in actively building bar formations downstream from Waco. The frequency of these bar formations decreases with proximity to Richmond, and Mathewson and Minter postulate that the reduced frequency of large discharges has reduced the capacity of the river to transport sediment through Richmond to the Gulf. They also attribute much of the coastal erosion in the vicinity of Sargent Beach (fig. 1) to sediment trapped in reservoirs and indicate that sand transport throughout the Brazos River has been reduced enough to account for the entire amount of sand lost in the coastal zone since at least 1937.

Seelig and Sorenson (1973) investigated shoreline changes at Sargent Beach and state that beach erosion is further aggravated by decreased sand input to the coast from the Brazos River because of alterations to the river and its drainage basin since the 1940s. They analyzed sand loads computed from TWDB and USGS samples at the Richmond streamflow-gaging station for water years 1922-65. Using mean annual concentrations of sediment load, they identified three periods with distinctly different suspended-sediment concentrations: (1) 1922-40, concentrations averaged about 5,000 parts per million (ppm), (2) 1941-50, concentrations declined steadily from 5,000 to $2,000 \mathrm{ppm}$, and (3) 1951-65, concentrations declined slightly but remained in the 1,000 to $3,000 \mathrm{ppm}$ range. They used methods developed by Colby (1957) and modified by C.T. Welborn (U.S. Geological Survey, written commun., 1970) to compute total loads of sand transported by the Brazos River to the coast. They identified a decline in sand transported to the coast and attributed this decline to the completion of a series of dams beginning with Possum Kingdom, improved soil conservation, and widespread transition from cotton production 
to grains and grazing in the Brazos Valley during World War II. They estimated that the construction of the dams in the 1940s reduced the rate of sand input to the coast to one-third of the rate before the 1940s.

Gillespie and Giardino (1997) describe and explain causative factors for the Brazos River channel migration. They hypothesize that reservoir construction immediately upstream of three study reaches has reduced the frequency of channel-forming discharges and has reduced sediment loads in the Brazos River as measured at the Richmond streamflow-gaging station (08114000). They analyzed total monthly and maximum daily discharge statistics at three USGS streamflow-gaging stations on the Brazos River (Waco [08096500], Bryan [08109000], and Hempstead [08111500]) and suspended-sediment concentrations measured by the TWDB at the Richmond streamflowgaging station. They divided the records into two parts: pre-1939 (pre-dam) and post-1939 (post-dam). Using Analysis of Variance (ANOVA), they found that predam discharge and sediment-concentration statistics are significantly greater than the post-1939 statistics. Gillespie and Giardino state that the results are consistent with a slowed rate of channel migration exhibited by the Brazos River in the post-dam period.

\section{Capacity of the Brazos River to Transport Sand}

Sediment is transported in a river as suspended load, as bed load by rolling and sliding along the bed, or both. Movement of sediment as suspended or bed load depends on the nature of the sediment (size, specific gravity, and shape) and the hydraulic characteristics of the flow. Generally, smaller particles such as silts and clays will move in suspension and larger sand-size particles will move both in suspension and as bed load. High-gradient streams have the capacity to transport appreciable quantities of sand- and gravel-sized particles in suspension, whereas low-gradient streams, transport most sand- and gravel-sized particles as bed load.

Velocity, depth, turbulence, and energy slope are the hydraulic characteristics that define the capacity of a river to transport sand-size sediment. For a given river, these characteristics will vary with the magnitude of flow; larger discharges will have a larger velocity, depth, turbulence, and energy slope than smaller discharges. Generally, only larger discharges develop the hydraulic characteristics necessary to transport appre- ciable quantities of sand-size or larger sediment in a river. The capacity of a river to transport sand depends on the frequency of discharges that develop the requisite hydraulic characteristics. As much as 90 percent of total sediment load in many streams is transported by flows that are equaled or exceeded about 10 percent of the time (Richardson and others, 1990).

The sediment load of a river can be divided into wash-load and bed-load fractions. The wash load is defined as those smaller particles, generally silt and clay, that remain in suspension over a wide range of discharges and are found in minimal quantities in the bed material. The wash load originates as wash-off from storm events within the watershed. The wash load depends primarily on the rate and source of supply; it is generally not correlated with the hydraulic characteristics of the channel. The bed load consists of particles in the bed material and is usually correlated strongly with hydraulic characteristics, and thus, discharge (Chang, 1988). The bed material of the Brazos River consists primarily of sand-size particles and gravel.

Incipient motion analysis can provide a rough indication of the capacity of a river to transport sand. When the hydraulic characteristics of a river are minimally sufficient to initiate movement of sand-size particles, the particles are moved along the streambed by the force of the flowing water. This force is characterized by the bed shear stress and can be computed for a given channel cross section as

$$
\tau_{\mathrm{o}}=\gamma \mathrm{DS},
$$

where

$\tau_{\mathrm{o}}$ is shear stress, in pounds per square foot;

$\gamma$ is unit weight of water, in pounds per cubic foot;

$\mathrm{D}$ is hydraulic depth (area divided by top width), in feet; and

$\mathrm{S}$ is bed slope, in feet per foot.

For a given sediment grain size, the critical shear stress necessary to initiate motion can be determined using the Shields diagram (Vanoni, 1975). The shear stress, $\tau_{0}$, resulting from a given discharge can be compared to the critical shear stress, $\tau_{c}$, for incipient motion to determine if the given particle size will be transported. When the shear stress is less than the critical shear stress, the flow does not have the capacity to transport sediment of the representative size; when the shear stress is greater than the critical shear stress, the given bed material will be transported. The median sediment size $\left(\mathrm{D}_{50}\right)$ represents the mesh size of a sieve 


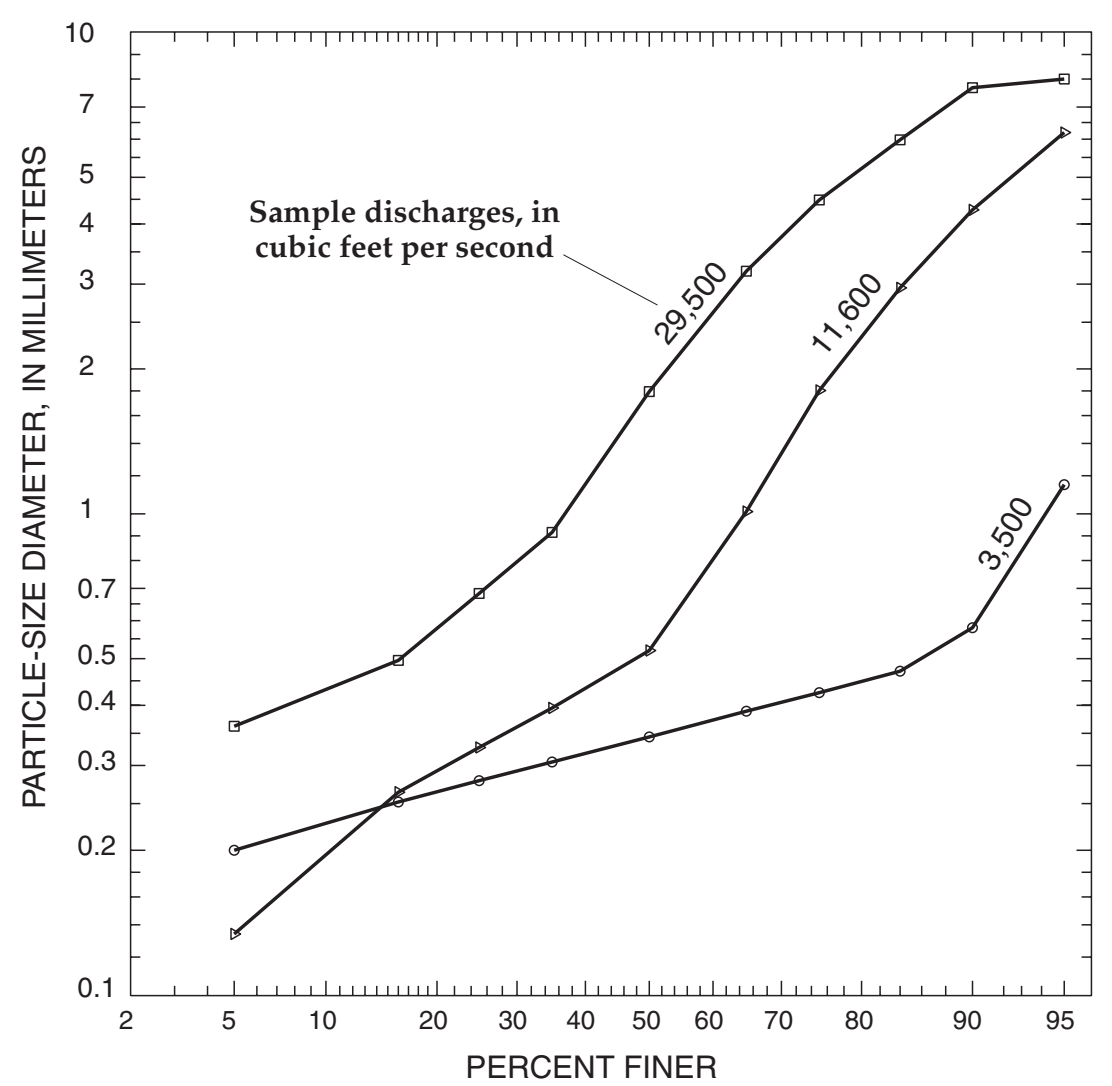

Figure 6. Particle-size distributions of bed material samples near streamflow-gaging station 08114000 Brazos River at Richmond, Texas.

through which 50 percent, by weight, of the material passes and commonly is used as the representative size of bed material for tractive-force and bed-material transport computations (Stelczer, 1981).

Bed-material samples were obtained from the main channel at a daily mean discharge of about $3,500 \mathrm{ft}^{3} / \mathrm{s}$ at the US 59 bridge 7 river miles downstream from the Richmond streamflow-gaging station during August 1991 for an unrelated study. Two additional samples were obtained from the main channel 3 river miles downstream from the Richmond streamflowgaging station in December 1996 and February 1997 at instantaneous discharges of 11,600 and $29,500 \mathrm{ft}^{3} / \mathrm{s}$, respectively. The samples were obtained using a US BMH-60 sampler, which obtains a 175-cubiccentimeter sample of bed material with a spring-loaded scoop. The scoop activates when the sampler contacts the bed and penetrates into the bed 1.7 in. (Guy and Norman, 1970). The shallow penetration of the sampler allows the capture of bed material that is most readily available for transport. Five to 10 individual samples were collected from the main part of the channel and were combined into a composite sample. The Shields diagram was used to compute the shear stress ratio for the $\mathrm{D}_{50}$ size for bed-material samples collected at three discharges. The particle-size distributions of the composite samples (fig. 6) were obtained using sieve analyses. The bed material coarsens substantially as discharge increases; the $\mathrm{D}_{50}$ increases from 0.34 to $1.79 \mathrm{~mm}$ over the range of discharges sampled.

The instantaneous discharges sampled $(3,500$, 11,600 , and $29,500 \mathrm{ft}^{3} / \mathrm{s}$ ) correspond to daily mean discharges with 46-, 20-, and 5-percent exceedance probabilities, respectively, for the 1903-95 period (excluding 1907-21) at the Richmond streamflowgaging station (fig. 7). Each sampled discharge has adequate capacity to initiate motion of the bed material on the basis of Shields diagram analysis (table 3 ). For the sample with $\mathrm{D}_{50}$ equal to $1.79 \mathrm{~mm}$, the ratio is greater than unity for all discharges larger than 


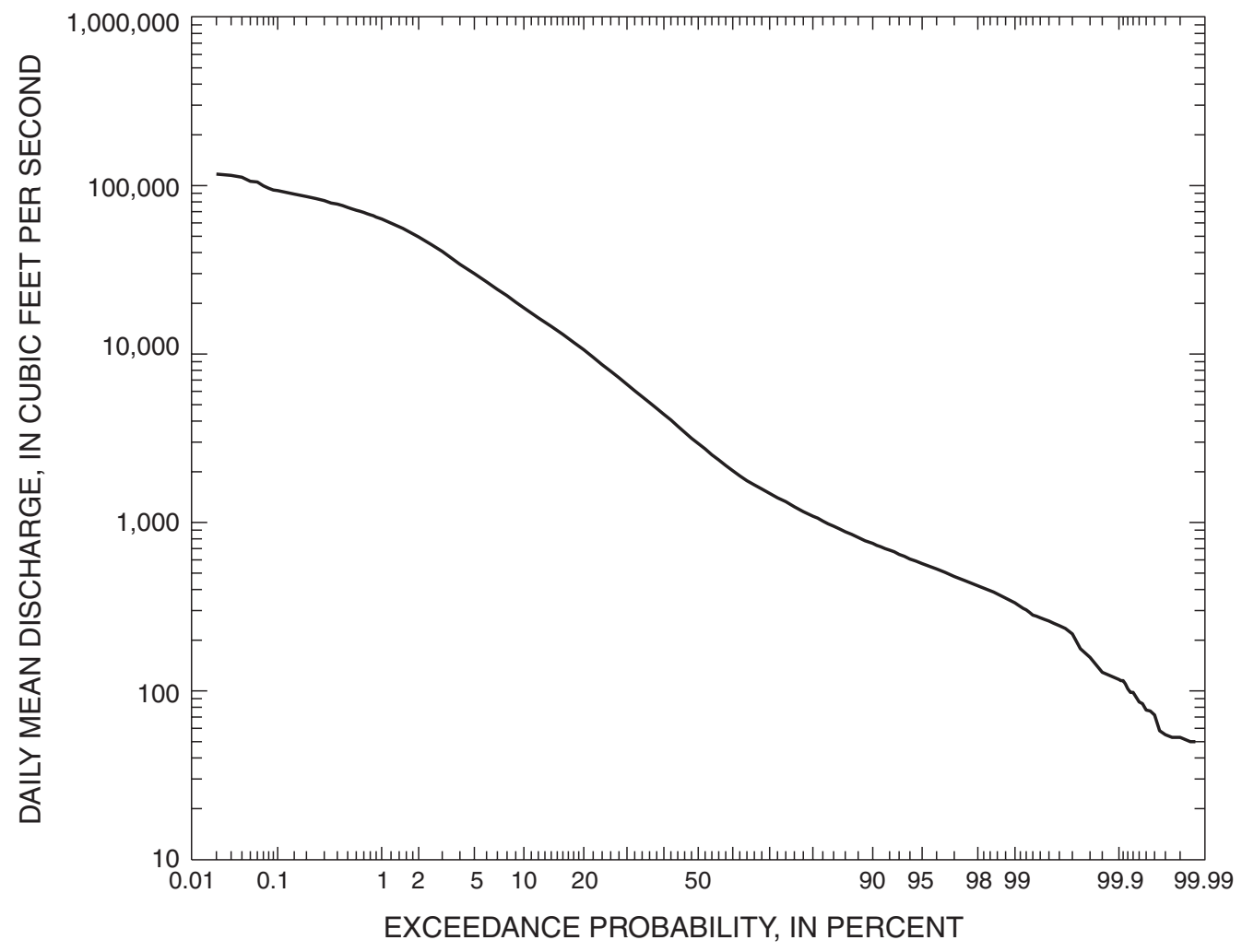

Figure 7. Flow-duration curve of daily mean discharge for streamflow-gaging station 08114000 Brazos River at Richmond, Texas, 1903-95 (excluding 1907-21).

$1,000 \mathrm{ft}^{3} / \mathrm{s}$ (82-percent exceedance probability). This indicates that the Brazos River has sufficient capacity to initiate motion of the bed material (as characterized by the $\mathrm{D}_{50}$ size) at least 82 percent of the time (fig. 7).

The motion analysis was repeated using the $\mathrm{D}_{85}$ size from each sampled discharge to examine the characteristics of the coarser fraction of bed material (table 3). For the sample with $\mathrm{D}_{85}$ equal to $5.98 \mathrm{~mm}$, the ratio is greater than unity for all discharges larger than about $17,000 \mathrm{ft}^{3} / \mathrm{s}$ (11-percent exceedance probability). This indicates that the Brazos River has sufficient capacity to initiate motion of the coarser bed material (as characterized by the $\mathrm{D}_{85}$ ) at least 11 percent of the time (fig. 7).

Table 3. Ratios of shear stress to critical shear stress required for initiation of motion at streamflow-gaging station 08114000 Brazos River at Richmond, Texas

$\left[\mathrm{D}_{50}\right.$ and $\mathrm{D}_{85}$, particle size for which 50 and 85 percent of the material is finer]

\begin{tabular}{|c|c|c|c|c|c|c|c|c|}
\hline $\begin{array}{c}\text { Discharge } \\
\text { (cubic } \\
\text { feet per } \\
\text { second) }\end{array}$ & $\begin{array}{c}\text { Hydraulic } \\
\text { radius } \\
\text { (feet) }\end{array}$ & $\begin{array}{c}\text { Shear } \\
\text { stress } \\
\text { (pounds } \\
\text { per square } \\
\text { foot) }\end{array}$ & $\begin{array}{c}\mathrm{D}_{50} \\
\text { (millimeters) }\end{array}$ & $\begin{array}{c}\text { Critical } \\
\text { shear } \\
\text { stress }^{1} \\
\text { (pounds } \\
\text { per square } \\
\text { foot) }\end{array}$ & $\begin{array}{l}\text { Ratio of } \\
\text { shear } \\
\text { stress to } \\
\text { critical } \\
\text { shear } \\
\text { stress }\end{array}$ & $\begin{array}{c}\mathrm{D}_{85} \\
\text { (millimeters) }\end{array}$ & $\begin{array}{c}\text { Critical } \\
\text { shear } \\
\text { stress }^{1} \\
\text { (pounds } \\
\text { per square } \\
\text { foot) }\end{array}$ & $\begin{array}{c}\text { Ratio of } \\
\text { shear } \\
\text { stress to } \\
\text { critical } \\
\text { shear } \\
\text { stress }\end{array}$ \\
\hline 3,500 & 6.10 & 0.0506 & 0.34 & 0.0043 & 11.8 & 0.47 & 0.0057 & 8.9 \\
\hline 11,600 & 11.47 & .0952 & .52 & .0058 & 16.4 & 2.95 & .0458 & 2.1 \\
\hline 29,500 & 18.70 & .1552 & 1.79 & .0242 & 6.4 & 5.98 & .1172 & 1.3 \\
\hline
\end{tabular}

${ }^{1}$ At assumed temperature of 15 degrees Celsius. 


\section{INDICATIONS OF CHANGE IN SAND TRANSPORT}

The transport of sediment in most rivers is affected by multiple interdependent factors that include land-use changes in the basin, natural erosion processes along the main stem and tributaries, basin hydrology (particularly extreme events), water-resource development, and human activities in the main channel. River morphology and sediment transport change continually as a river adjusts in response to changes in these and other factors.

River channels will adjust to minimize energy dissipation, and these adjustments affect the capacity to transport the available sediment with the available water discharge. Channel adjustment processes can be characterized by the qualitative relation set forth by Lane (1955),

$$
\mathrm{QS} \sim \mathrm{Q}_{\mathrm{S}} \mathrm{D},
$$

where

$\mathrm{Q}$ is river discharge;

$\mathrm{S}$ is river slope;

$\mathrm{Q}_{\mathrm{S}}$ is bed-sediment discharge; and

$\mathrm{D}$ is a characteristic particle-size diameter.

Lane's relation states that the product of river discharge and river slope is proportional to the product of the bed-sediment discharge and a characteristic particlesize diameter. The river slope can refer to either the channel slope or the slope of the energy-grade line of the river but is usually taken as the latter.

If one or more of these four variables are modified, then one or more of the remaining variables will change to maintain the proportional relation. These changes can occur rather suddenly, as in response to abrupt disturbances such as channel shortening or straightening (Robbins and Simon, 1983); but often the changes will occur over long periods of time in response to more subtle disturbances such as land-use changes. Observed changes in channel characteristics might be remnant responses to disturbances that occurred decades earlier. Present-day channel responses usually cannot be attributed to one causative factor but to a combination of recent and historical factors.

Using the concepts described by Lanes's relation, if the size of sediment available for transport and the dominant discharge (discharge with about a 1 to 2.5year recurrence interval) remain constant, then construction of a dam will decrease the energy slope of the river upstream from the dam. The sediment discharge also will decrease because of the reduced transport capacity of the river. The river will agrade (sediment will accumulate in the channel), and the size of the sediment transported likely will decrease. Downstream from the dam, if the dam traps the majority of the bed material and does not affect the dominant discharge, the channel would be expected to adjust the slope to maintain the proportional relation. The channel likely would erode downward (down-cut) to reduce the slope. In this case, the bed material eroded from downcutting - and bank material from subsequent bank failures - is made available for transport, and the sediment supply increases somewhat, at least temporarily. This illustrates the complexity of the river-adjustment phenomenon, which has been referred to by Thornes (1977) as having "indeterminacy" and "equifinality;" meaning, respectively, that a channel can respond to changes in many different ways, and a given response can be caused by several different factors. In actuality, all of the variables are changing at any given time, and a river remains in a state of continual adjustment toward dynamic equilibrium. If, however, one of the variables undergoes consistent long-term change, then the river can be expected to exhibit corresponding long-term change in accordance with Lanes's relation.

Changes in the capacity of a river to transport sand can be identified within the context of Lane's relation through changes in slope indicated by changes in channel geometry, changes in the characteristics of suspended loads, and changes in discharge. Total sediment-discharge data can be analyzed directly if available, but total sediment discharge rarely is measured because of the expense and difficulty of collecting the required bed-load data. However, suspended-sediment data are collected routinely by the USGS and other agencies and can be used as an indicator of changes in the sediment-transport characteristics of a river. Changes in suspended-sand load, if particle sizes of the suspended load have been determined, can be used to infer changes in the total sand load. All of these indicators, used conjunctively, provide evidence for concluding whether change in the sand-transport characteristics of a river has taken place.

\section{Changes in Channel Geometry}

Adjustment of river slope in response to changes in sediment supply and discharge often manifests as changes in channel geometry such as 


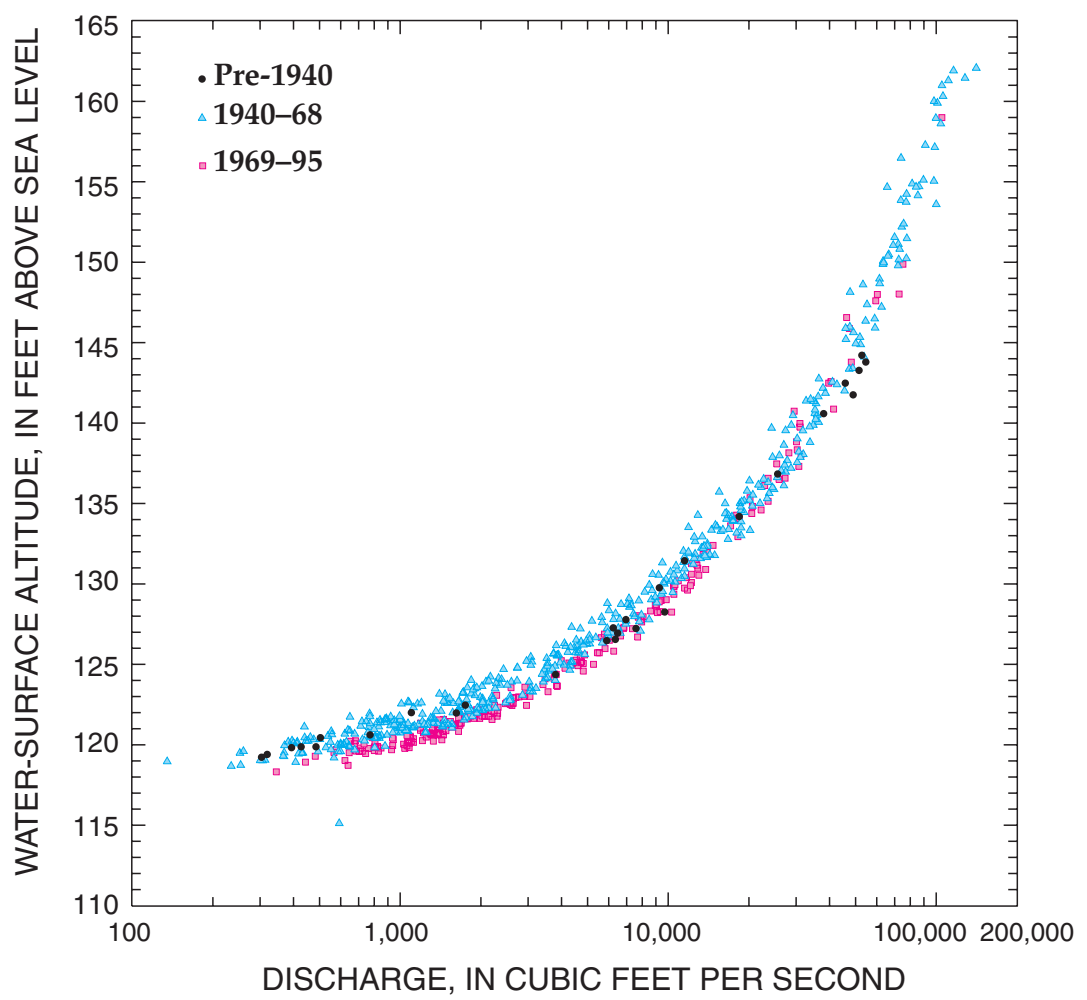

Figure 8. Stage-discharge relation at streamflow-gaging station 08111500 Brazos River near Hempstead, Texas.

channel agradation or incision and channel widening. Streamflow-gaging-station records and surveyed channel geometry are sources of information from which to measure geometric adjustments of a river.

Discharge measurements made at streamflowgaging stations over time can be used to identify changes in the channel characteristics. The Richmond streamflow-gaging station has been operated continually since 1925 at its present location and had 902 measurements available at the time of this study; the Hempstead streamflow-gaging station since 1938 with 746 measurements; and the Rosharon streamflowgaging station since 1967 with 241 measurements. Occasionally the streamflow-gaging-station datum is changed, so all stages have been converted to altitude above sea level.

The stage-discharge relations for the Hempstead, Richmond, and Rosharon streamflow-gaging stations are shown in figures $8-10$. The measurements are differentiated by time period-pre-1940 (except Rosharon), 1940-68, and 1969-95. Long-term changes in the stage-discharge relations are indicated: At discharges below about $30,000 \mathrm{ft}^{3} / \mathrm{s}$, the water-surface altitude has declined several feet. At discharges above $30,000 \mathrm{ft}^{3} / \mathrm{s}$, this trend is not apparent.

An analysis was done to estimate the rate of change of the water-surface altitude for a particular discharge. Water-surface altitude was regressed with discharge for all of the discharge measurements in a moving 5-year window for the entire period of each station's record using a quadratic function of the form

$$
\mathrm{A}=\mathrm{B}_{1}+\mathrm{B}_{2} \mathrm{Q}+\mathrm{B}_{3} \mathrm{Q}^{2},
$$

where

A is water-surface altitude;

$\mathrm{B}_{1}, \mathrm{~B}_{2}$, and $\mathrm{B}_{3}$ are regression coefficients; and $\mathrm{Q}$ is discharge.

The regression equation for a given year was based on the discharge measurements made during the 5-year period starting 2 years before and ending 2 years after the given year. The water-surface altitude corresponding to a discharge of $5,000 \mathrm{ft}^{3} / \mathrm{s}$ was computed using the individual regressions for each year for which the full 5-year window of measurements was available.

The water-surface altitudes at a discharge of $5,000 \mathrm{ft}^{3} / \mathrm{s}$ for the three streamflow-gaging stations are 


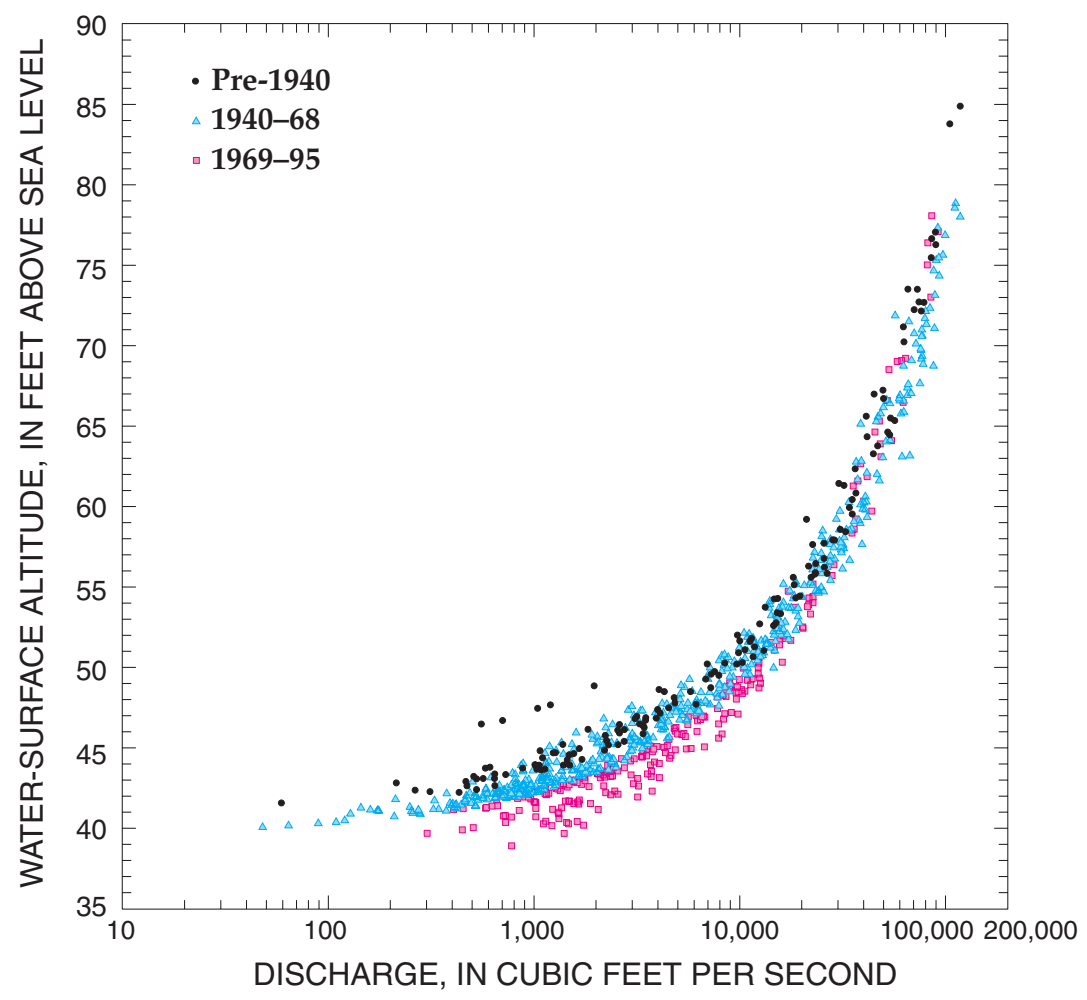

Figure 9. Stage-discharge relation at streamflow-gaging station 08114000 Brazos River at Richmond, Texas.

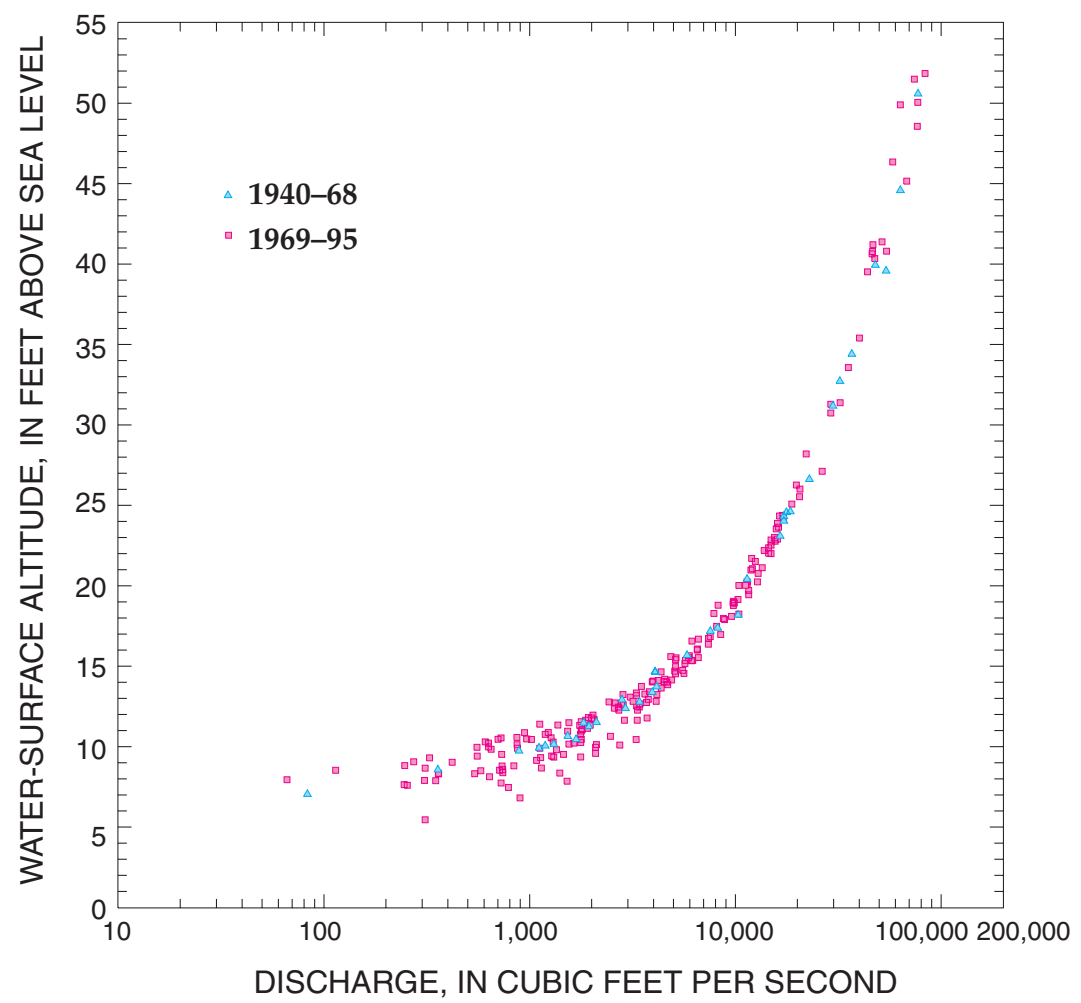

Figure 10. Stage-discharge relation at streamflow-gaging station 08116650 Brazos River near Rosharon, Texas. 


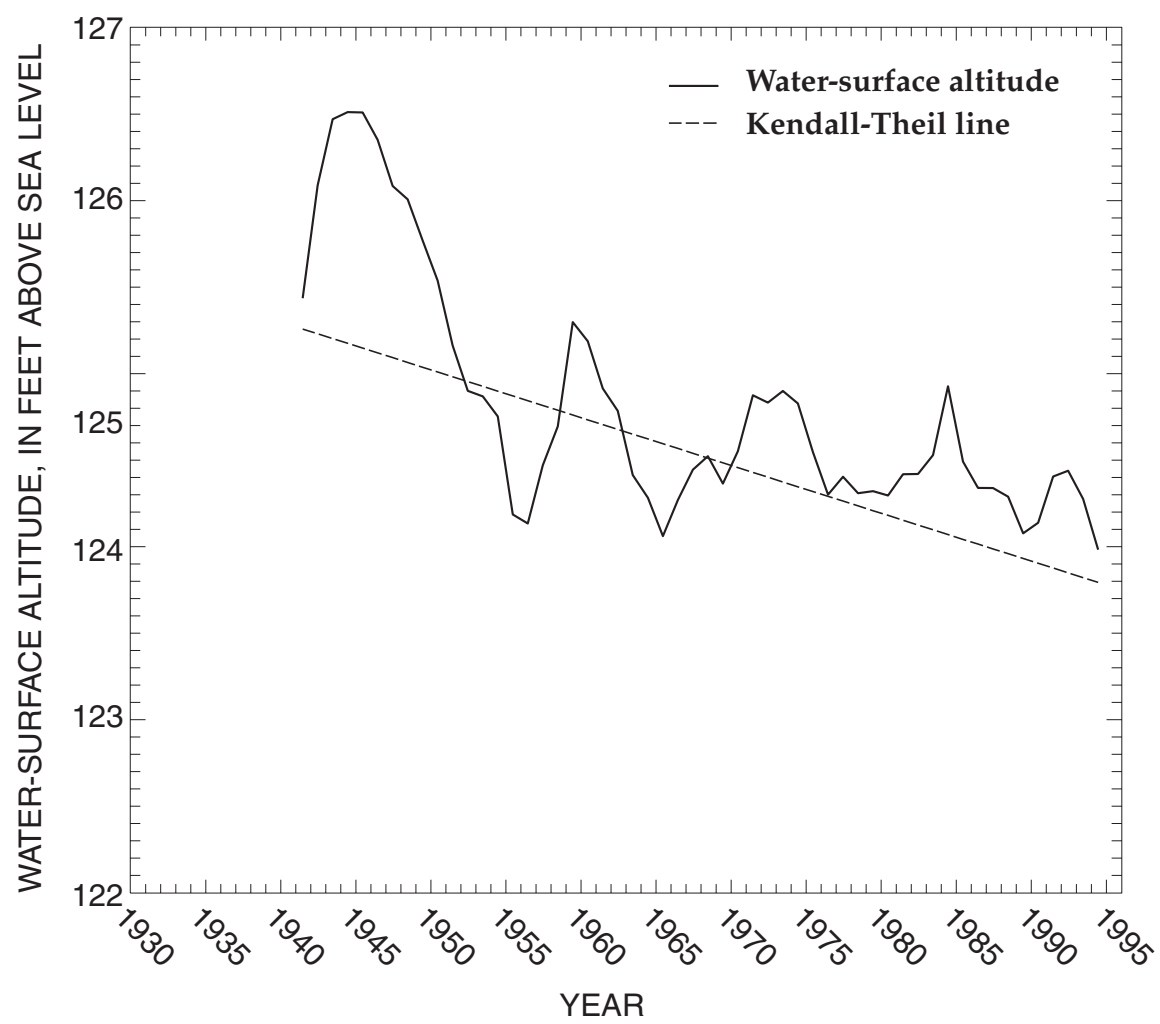

Figure 11. Water-surface altitudes at a discharge of 5,000 cubic feet per second at streamflow-gaging station 08111500 Brazos River near Hempstead, Texas.

shown in figures 11-13. A non-parametric KendallTheil line (Helsel and Hirsch, 1992) was fit to the data to determine the long-term slope. The Kendall-Theil line defines the monotonic relation between two variables, in this case water-surface altitude and time. The analysis indicates that the long-term decline in water-surface altitude for a discharge of $5,000 \mathrm{ft}^{3} / \mathrm{s}$ has been about $0.028 \mathrm{ft} / \mathrm{yr}$ for the Hempstead streamflowgaging station, about $0.056 \mathrm{ft} / \mathrm{yr}$ for the Richmond streamflow-gaging station, and $0.066 \mathrm{ft} / \mathrm{yr}$ for the Rosharon streamflow-gaging station. The slopes of the lines are statistically significant $(\mathrm{p}<0.00003)$.

The data at the Hempstead and Richmond streamflow-gaging stations also demonstrate cyclical patterns in the monotonic trends that match very closely from 1940 to about 1965 (figs. 11, 12). The overall decreases in the water-surface altitude at the three streamflow-gaging stations indicate that the transport characteristics of the river changed, which is consistent with a decreased supply of sand-size sediment in the river.

\section{Changes in Suspended-Sediment Characteristics}

During 1969-95, 215 periodic samples for measurement of suspended-sediment concentration were taken at the Richmond streamflow-gaging station over a range of discharge from 445 to $88,100 \mathrm{ft}^{3} / \mathrm{s}$. The percent fines (generally silt and clay, with size less than $0.062 \mathrm{~mm}$ ) was determined for 208 of the samples. The percent of sand in each sample was computed by subtracting the percent fines from 100 percent. Four samples seemed to have erroneous concentrations and were excluded from the analysis. The percent sand in each sample was multiplied by the suspended-sediment concentration to compute the suspended-sand concentration (fig. 14).

The suspended-sand concentrations apparently decreased, starting about 1982. Suspended-sand concentrations typically will decrease as discharge decreases, so decreases in suspended-sand concentrations could be attributed to systematically smaller sampled discharges. Such changes in sampled discharge over time could have a substantial temporal effect 


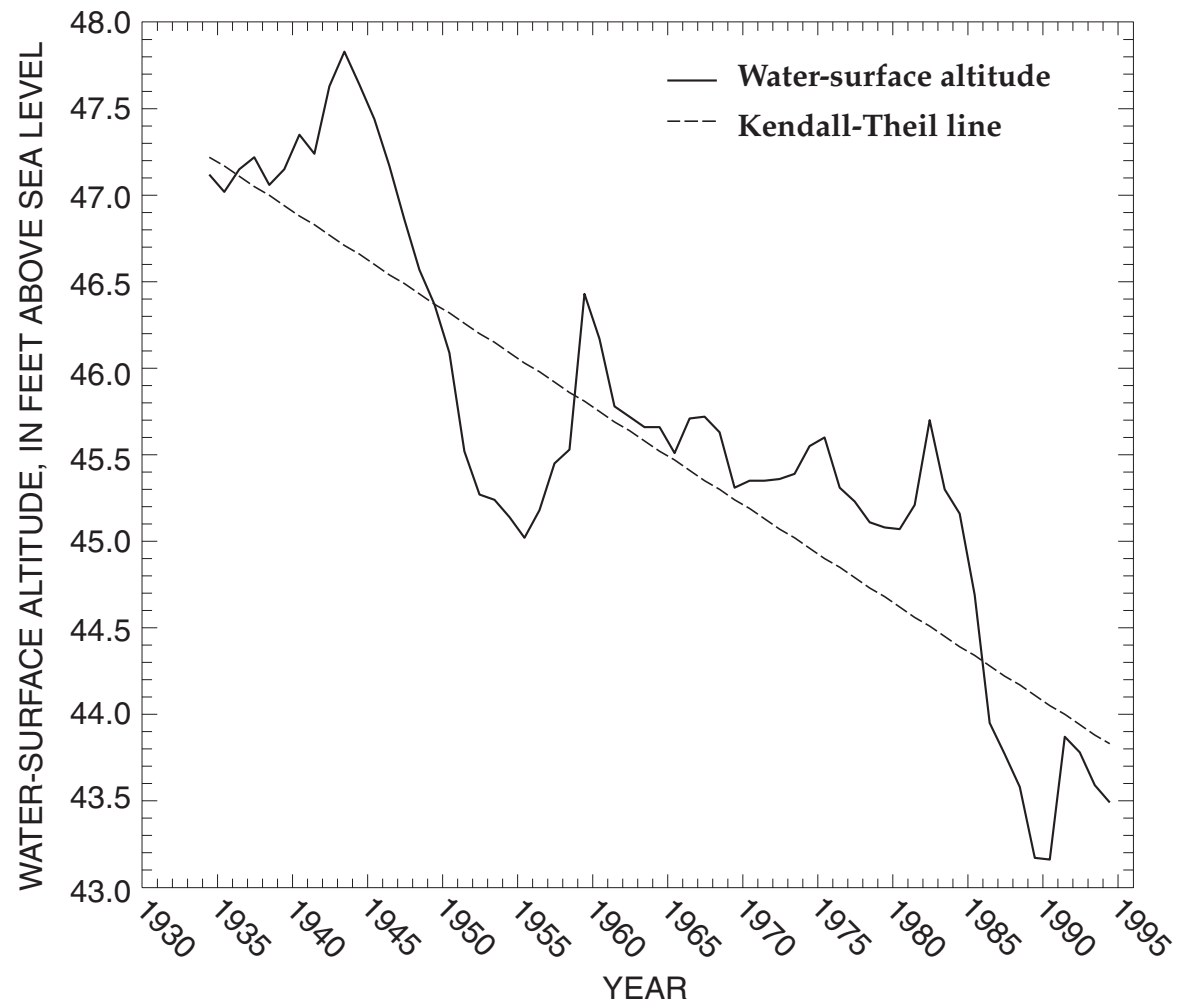

Figure 12. Water-surface altitudes at a discharge of 5,000 cubic feet per second at streamflow-gaging station 08114000 Brazos River at Richmond, Texas.

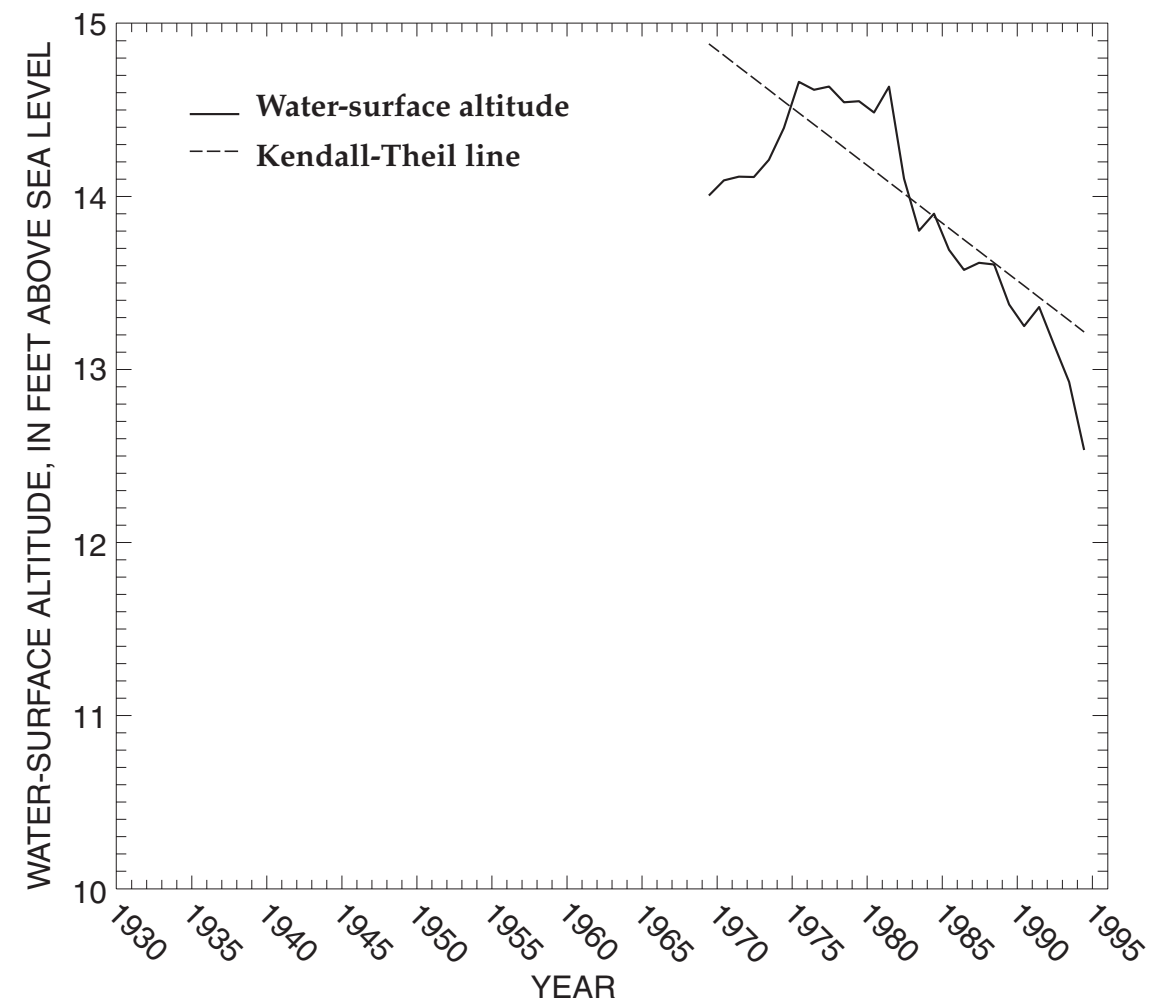

Figure 13. Water-surface altitudes at a discharge of 5,000 cubic feet per second at streamflow-gaging station 08116650 Brazos River near Rosharon, Texas. 


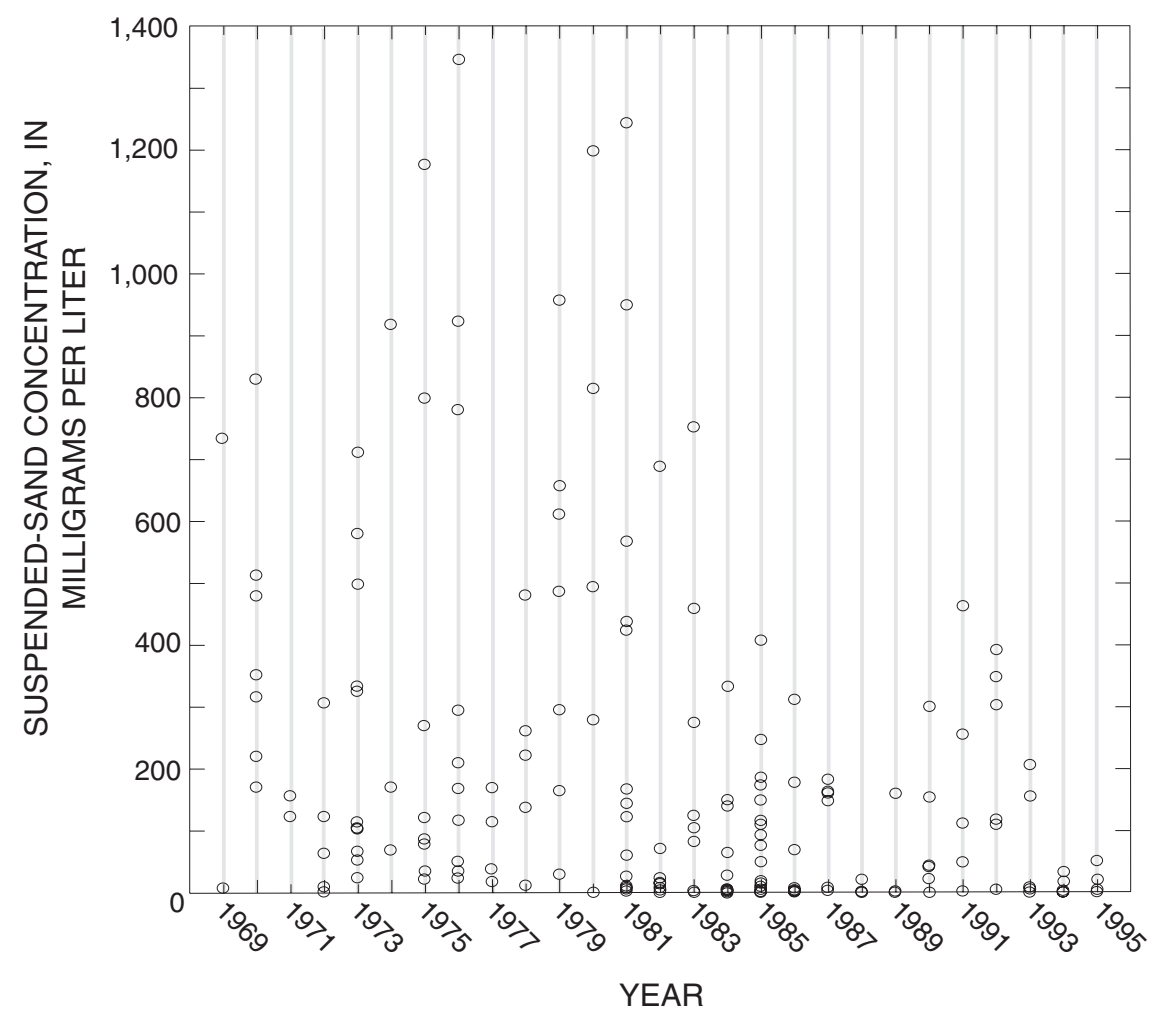

Figure 14. Suspended-sand concentrations in samples at streamflow-gaging station 08114000 Brazos River at Richmond, Texas, 1969-95.

on suspended-sand concentrations. The discharges sampled, which ranged from 445 to $88,100 \mathrm{ft}^{3} / \mathrm{s}$ are shown in figure 15 . The Wilcoxon rank-sum test (Helsel and Hirsch, 1992) was applied to test for differences between the median minimum and median maximum discharges sampled during 1969-81 and 1982-95. The median of the yearly minimum sampled discharges for $1969-81\left(2,649 \mathrm{ft}^{3} / \mathrm{s}\right)$ is significantly larger $(\mathrm{p}=0.011)$ than the median for $1982-95\left(1,145 \mathrm{ft}^{3} / \mathrm{s}\right)$. No change was detected in the maximum discharges sampled each year $(p=0.41)$ nor in the range of discharges sampled $(\mathrm{p}=0.45)$. These tests indicate that more samples were collected at generally smaller discharges during 1982-95 but that the maximum discharge sampled each year did not change significantly. About equal numbers of samples were taken above $2,000 \mathrm{ft}^{3} / \mathrm{s}$ (median daily discharge) for both periods (81 samples during 1969-81 and 86 during 1982-95) — in other words, median sampled discharge was about the same for both periods. The apparent change in the suspended-sand concentrations cannot be attributed to a change in the discharges sampled.
LOcally WEighted Scatterplot Smoothing (LOWESS) lines (Cleveland, 1979) were fit to 1969-81 and 1982-95 suspended-sand concentration as a function of discharge (fig. 16). For discharges larger than $1,000 \mathrm{ft}^{3} / \mathrm{s}$, the suspended-sand concentrations of samples taken during 1969-81 were greater than those taken during 1982-95 for similarly sampled discharges. The LOWESS lines provide a graphical comparison between the two periods but do not assign a statistical significance to the difference.

A LOWESS line was fit to the suspended-sand versus discharge graph with no temporal differentiation, and residuals from that line were computed (residual equals LOWESS minus measured). The residuals represent concentration, adjusted to remove any relation to discharge. Residuals thus computed can be identified as "flow-adjusted residual concentrations" (Helsel and Hirsch, 1992). A Wilcoxon rank-sum test indicates that the median residual concentration during 1969-81 is significantly less than the median residual concentration during 1982-95 ( $\mathrm{p}<0.00005)$, which provides strong statistical evidence that the suspended-sand 


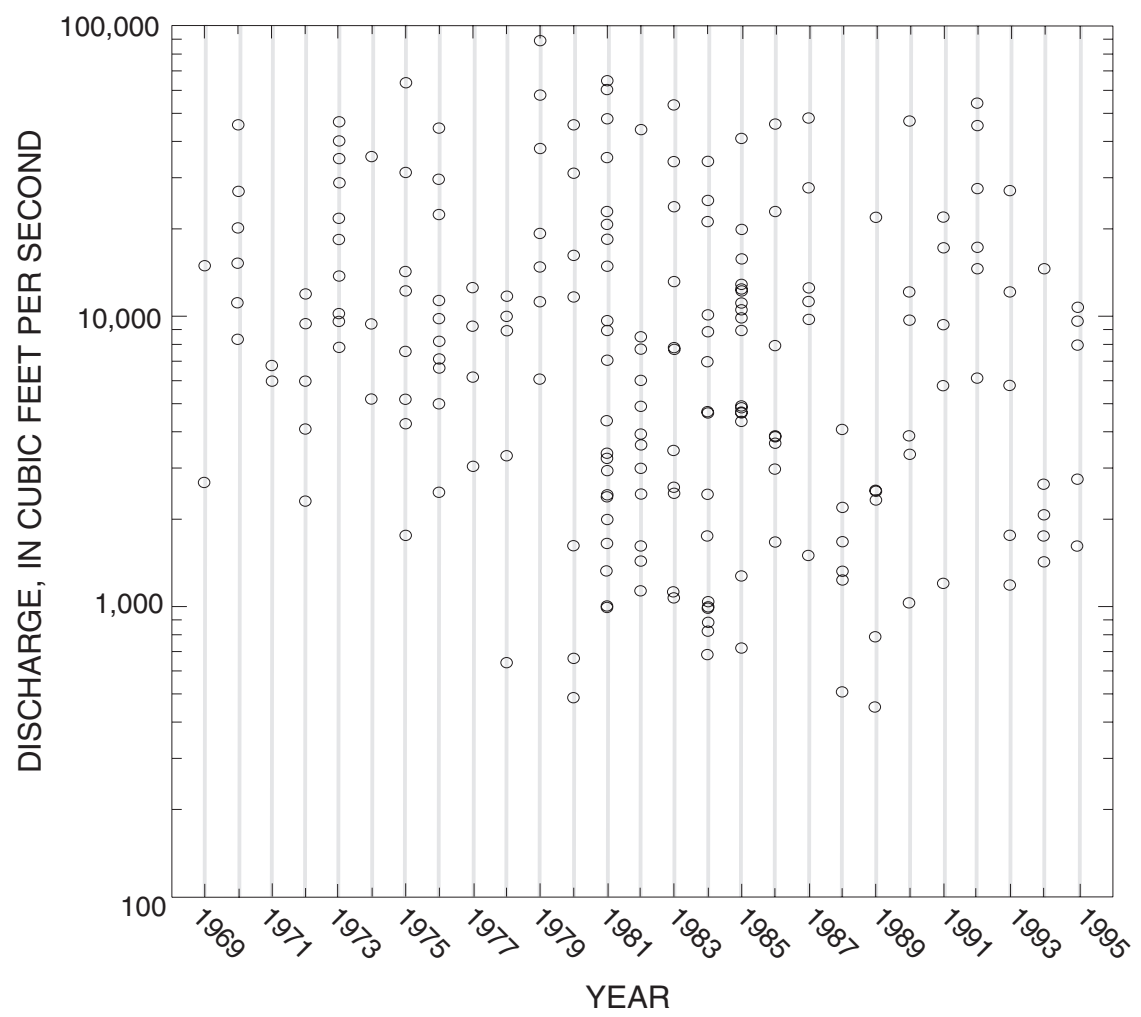

Figure 15. Sampled discharges at streamflow-gaging station 08114000 Brazos River at Richmond, Texas, 1969-95.

concentration at a given discharge decreased during 1982-95.

The suspended-sediment samples contained less than 35-percent sand-size particles. A LOWESS line fit to a graph of percent sand versus discharge (fig. 17) indicates that the percent sand increased at discharges larger than about $5,000 \mathrm{ft}^{3} / \mathrm{s}$. Residuals computed from this LOWESS line represent the percent sand independent of discharge. A Wilcoxon rank-sum test indicates that the median residual percentage of sand during 1969-81 is significantly smaller than the median during 1982-95 ( $\mathrm{p}=0.084)$, which indicates that the percent sand at a given discharge also decreased during 1982-95.

These analyses indicate that suspended-sand concentrations in the Brazos River at Richmond for a given discharge decreased during 1982-95. Both suspended-sand concentrations and the percentage of sand in suspension decreased. These decreases could be caused by a change in the hydraulics of the flow at the measurement cross section. A decrease in the channel velocity would cause more of the sediment to be transported as bed load, which would not be measured by a suspended-sediment sampler. However, a graph of discharge and mean velocity for all measurements during 1969-95 (fig. 18) indicates that mean velocities have not decreased. LOWESS lines were fit to this graph for all discharge measurements made from the US 90-A bridge. The median residuals for the two periods are not significantly different $(p=0.24)$. However, this $p$-value does indicate some weak evidence that the mean velocity has changed.

Velocity varies across a cross section, and the suspension of sand will vary accordingly. Only a small fraction of the cross section can sustain velocities and shear stresses capable of transporting sand in suspension; as the velocity in this part of the cross section decreases, the transport of sand in suspension likely will decrease. If the mean velocity remains constant, the corresponding increase in velocity over the remainder of the cross section might be insufficient to increase the transport of suspended sand. For this reason, the mean velocity might not be a sufficient indicator of the hydraulic capacity of a stream to transport sand in suspension. The maximum velocity measured in the cross section during each discharge measurement might 


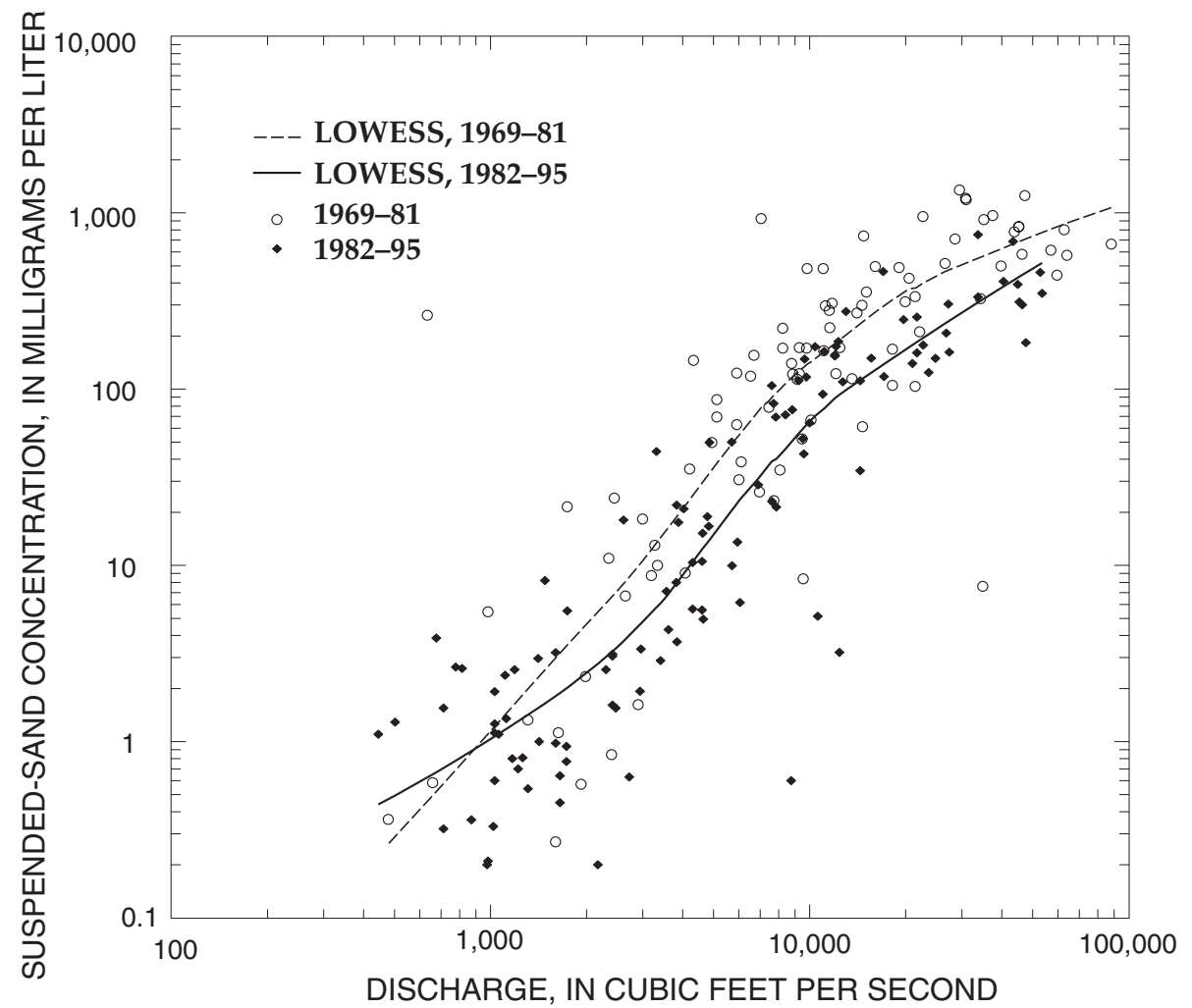

Figure 16. Relation of suspended-sand concentration to discharge at streamflow-gaging station 08114000 Brazos River at Richmond, Texas, 1969-95.

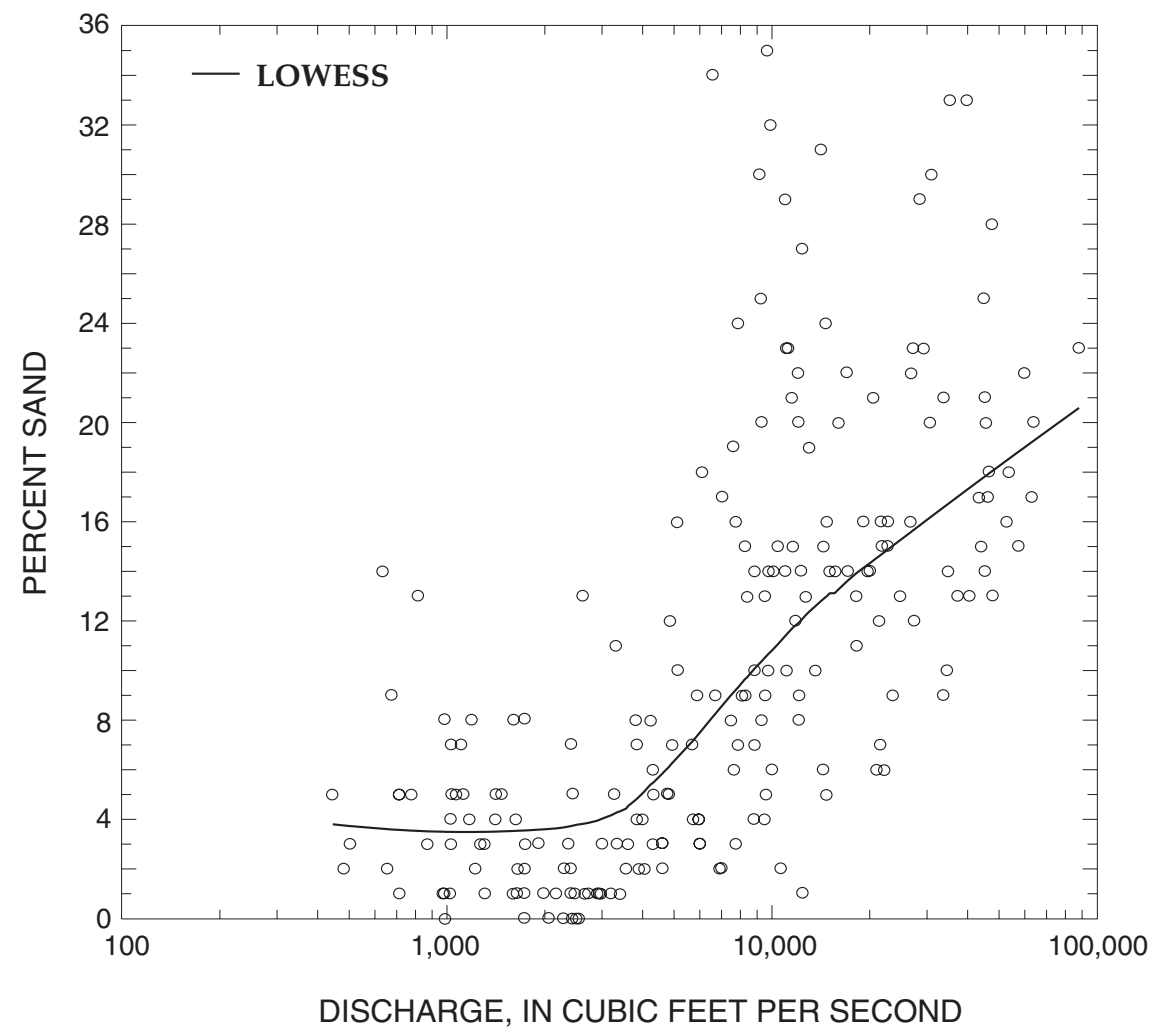

Figure 17. Relation of percent sand in suspended-sediment samples to discharge at streamflow-gaging station 08114000 Brazos River at Richmond, Texas, 1969-95. 


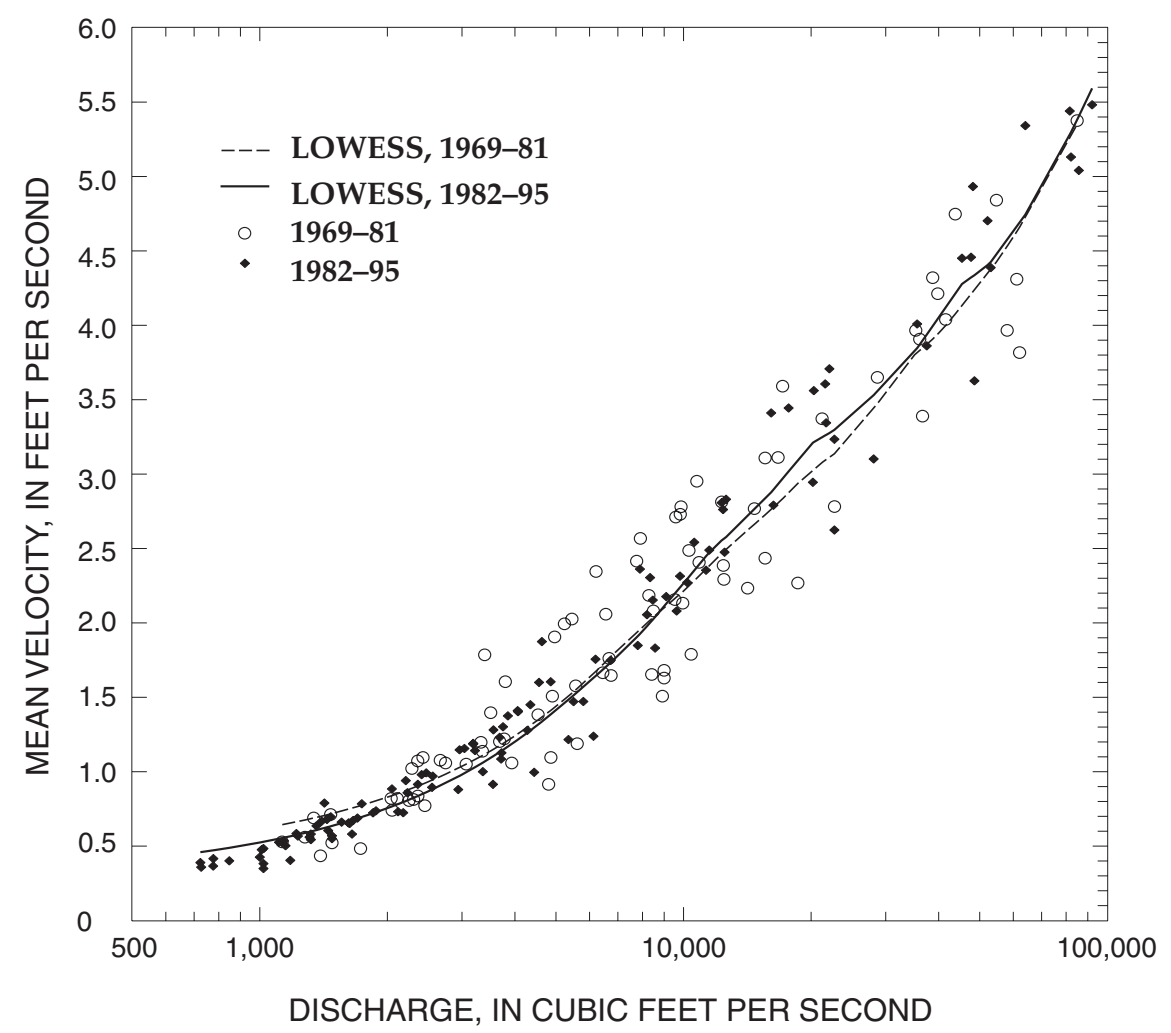

Figure 18. Relation of mean channel velocity to discharge at streamflow-gaging station 08114000 Brazos River at Richmond, Texas, 1969-95.

provide a better indication of reduced transport capacity. A decrease in the maximum velocity in the cross section for a given discharge would provide some explanation for the decrease in suspended sand measured. A LOWESS line was fit to a graph of discharge versus the maximum velocity in the cross section for the measurements made during 1969-95. The residuals from that LOWESS line do not indicate that the maximum velocity in the cross section decreased for a given discharge during 1982-95 $(\mathrm{p}=0.440)$.

The depth at the cross-section location at which the maximum velocity was measured was derived from the discharge measurements. A LOWESS line was fit to the graph of mean velocity versus this depth, which closely approximates the maximum depth in the cross section. The residuals from this LOWESS line indicate that for a given mean velocity, the depth of the cross-section location of maximum velocity was about $3.6 \mathrm{ft}$ deeper during 1969-81 than during 1982-95 ( $\mathrm{p}<0.00005)$. The mean channel depth and channel width were similarly analyzed, and the results indicate that the mean channel depth was greater and the channel width was narrower during 1969-81 than during 198295 ( $\mathrm{p}<0.00005$ ). However, no change in the crosssectional area of the channel was detected.

Although the maximum velocity in the cross section has not changed at a level near statistical significance, the change in mean velocity could be considered weakly significant $(\mathrm{p}=0.24)$. Coupled with changes in other characteristics known to affect the capacity of the channel to transport sediment, a subtle change in the mean velocity might affect a channel's transport capacity.

Shear stress developed in a channel (eq. 1) is an indicator of the capacity of a channel to transport sediment. A change in shear stress can therefore reflect a change in the capacity of a channel to transport sediment. Assuming that the overall bed slope of the channel and the unit weight of water remain constant, a change in the hydraulic depth will signal a change in shear stress. A LOWESS line was fit to a hydraulic depth versus discharge graph. The residuals from the LOWESS line changed significantly over time $(\mathrm{p}<0.01)$, indicating that the channel has a reduced 


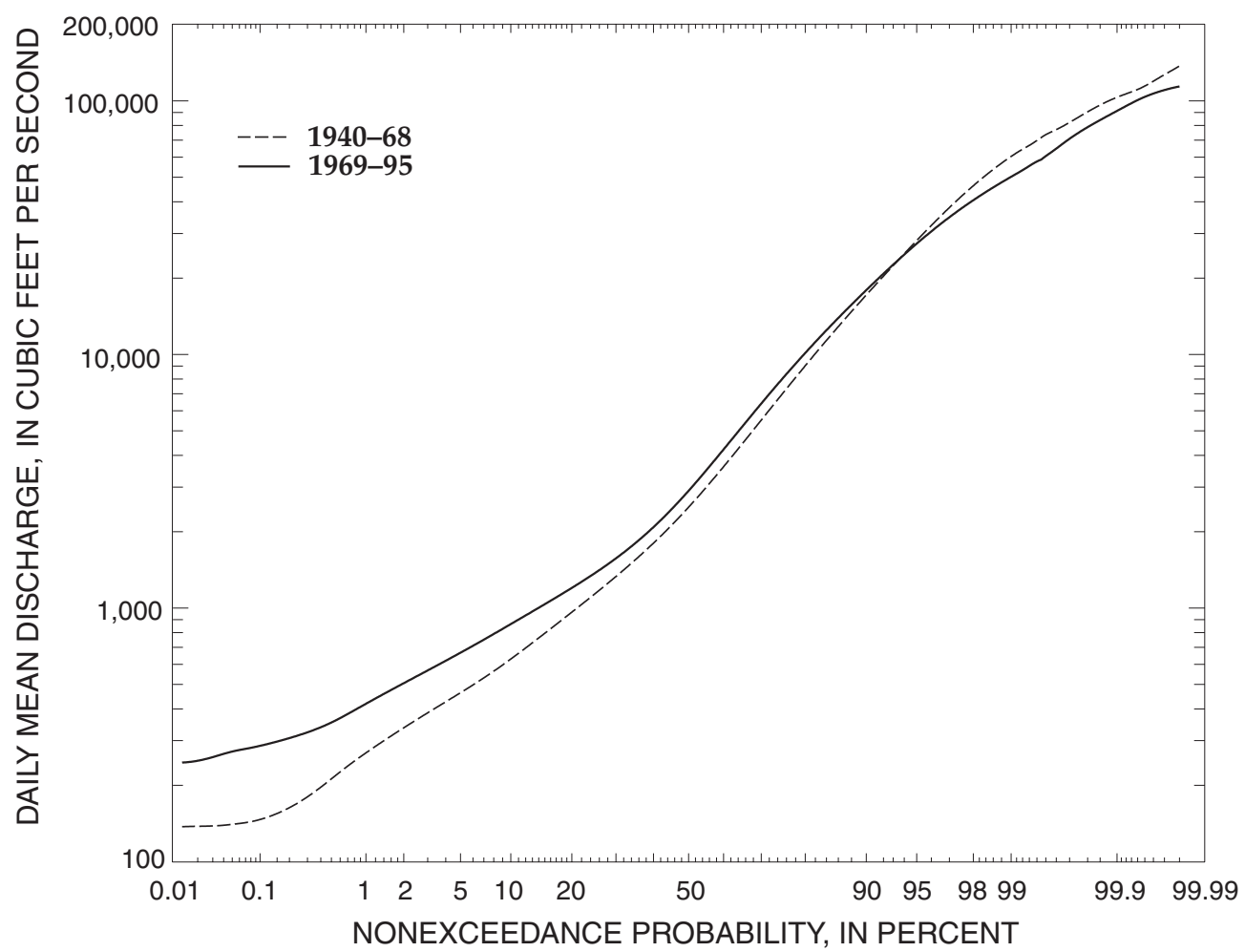

Figure 19. Flow-duration curves of daily mean discharge for streamflow-gaging station 08111500 Brazos River near Hempstead, Texas, 1940-68 and 1969-95.

capacity to transport sand-size sediment because of a reduction in shear stress developed by the channel.

In summary, no statistically significant change was detected in the mean or maximum channel velocity, but some evidence exists that suggests the mean channel velocity decreased during 1982-95. The channel depth has decreased as the channel width has increased; the resulting water-surface altitude has decreased, and the hydraulic depth related to shear stress has decreased. These changes in channel geometry might be responsible for the apparent changes in suspended-sand transport. The apparent changes in suspended-sediment transport cannot be attributed to changes in the sampling or laboratory methods, which have remained constant since the start of the sampling at the Richmond station. In the late 1980s, the bridge from which all measurements had been taken was removed, and a new bridge was constructed at the same location.

\section{Changes in Discharge}

Sand discharge in a river varies greatly with water discharge. Sand will not be transported in substantial quantities until the channel develops sufficient hydraulic characteristics, which usually occur during larger (above-average) flows. Changes in the magnitude and frequency of larger discharges can be caused by changes in land use, such as rapid urbanization; longterm climatic changes; diversion for flood control; and reservoir construction, both for flood control and water supply. Of these, the most likely to influence large flows in the Brazos River is reservoir construction, particularly those reservoirs constructed for flood control. Flows in the Brazos River are unlikely to be influenced by urbanization, simply because the size of the basin is large relative to the size of the urban areas within. The effects of long-term climatic changes will be more gradual than the effects of reservoir construction, considering the extent of reservoir construction in the basin.

Reservoirs can affect the distribution of both daily and annual-peak discharges. Flow-duration curves of daily mean discharge at the Hempstead and Richmond streamflow-gaging stations are shown in figures 19 and 20. The records have been divided into two (for Hempstead) or three (for Richmond) periods: early (pre1940), middle (1940-68), and late (1969-95). These periods roughly correspond to periods in which the rate 


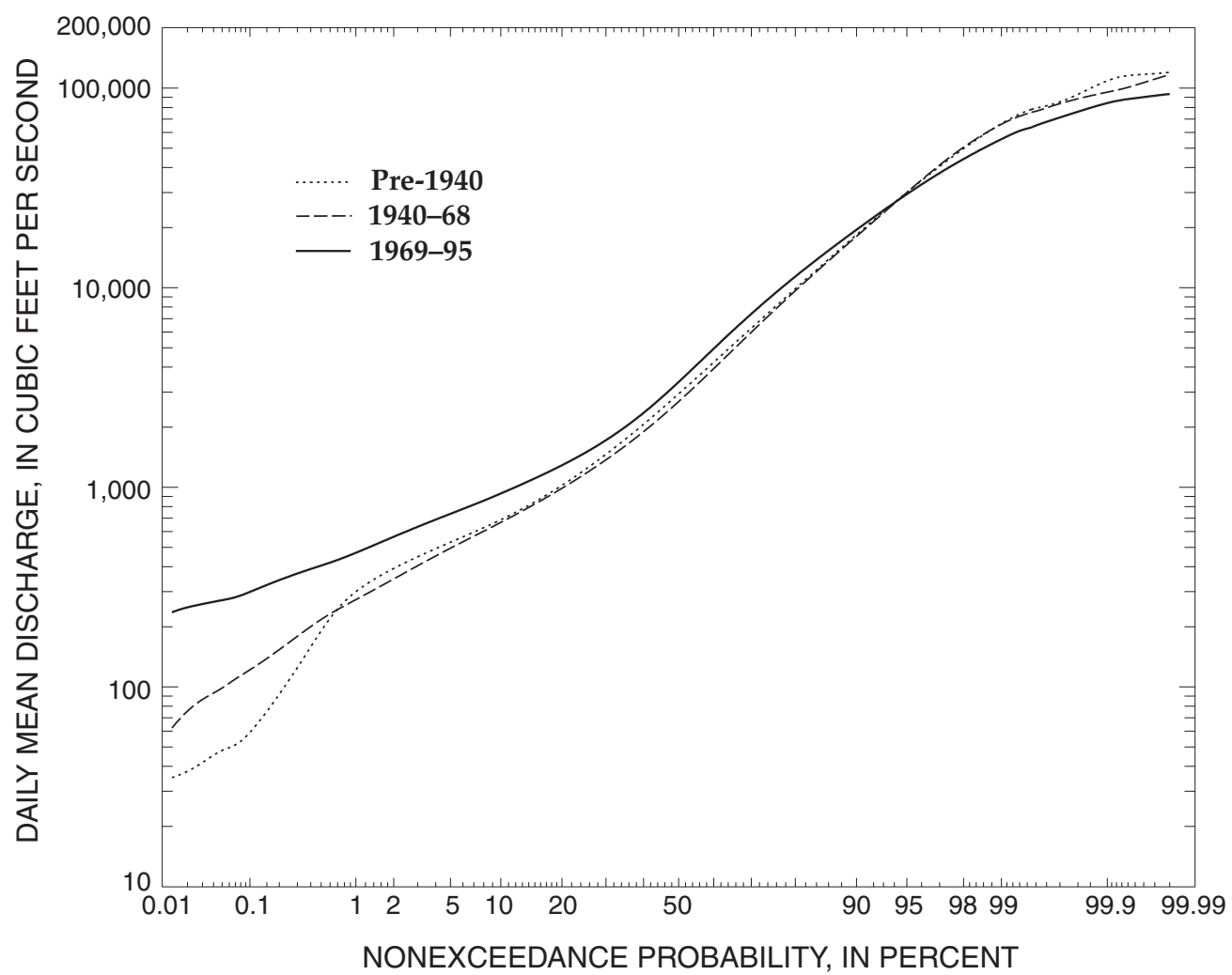

Figure 20. Flow-duration curves of daily mean discharge for streamflow-gaging station 08114000 Brazos River at Richmond, Texas, pre-1940, 1940-68, and 1969-95.

of increase in reservoir storage was distinctly different. The differences in the distributions are typical of changes in discharge downstream from reservoirs-the lower-tail discharges are increased as a result of controlled releases, and the upper-tail discharges are reduced as a result of regulation for flood control.

The upper parts of the curves at both streamflowgaging stations do not differ substantially until about the 4-percent exceedance probability (which indicates the discharge that was equaled or exceeded during 4 percent of the days in the period-about $30,000 \mathrm{ft}^{3} / \mathrm{s}$ ). At 4-percent and greater exceedance probabilities, the magnitudes of discharge at given frequencies of occurrence are substantially different. The 1-percent discharge at Hempstead changed from about 61,000 $\mathrm{ft}^{3} / \mathrm{s}$ during 1940-68 to 50,000 $\mathrm{ft}^{3} / \mathrm{s}$ during 1969-95. The 1-percent discharge at Richmond changed little from pre-1940 to $1940-68\left(67,000 \mathrm{ft}^{3} / \mathrm{s}\right)$ but changed to $55,700 \mathrm{ft}^{3} / \mathrm{s}$ during 1969-95.

Comparing flow-duration curves gives only a preliminary indication that the distribution of daily flows at the streamflow-gaging stations has changed. Many of the discharges in the upper tails of the distributions likely are from the same hydrologic events and thus are not independent. Enough daily discharges exist that several independent events are included in the upper tails of the distributions; however, the distributions only imply that differences in flows between periods exist without assigning a level of statistical significance to support the implication.

The distributions of daily discharge at the Richmond streamflow-gaging station were investigated on an annual basis by computing flow percentiles for each annual series of daily discharge. The daily discharges composing the distribution in each year likely are not independent, but the distributions from year to year can be considered independent. Upper-tail percentiles $(50,75,80,83.3,87.5,90,95,98$, and 99) were computed for each year of both periods. The early period contains 21 complete years of daily streamflow record for which flow percentiles were computed. The late period contains 27 years, so for each flow percentile, the 27 values were converted to an equivalent 21 year series using order statistics (David, 1981; Kaigh and Driscoll, 1987). The order statistics preserve the underlying statistical distribution of a sample series 
while compressing its size and are ideal for comparing the distributions of samples of unequal sizes.

For each flow percentile, two tests were done to identify differences between the periods. Wilcoxon rank-sum tests were done to test for differences in the medians of each of the percentiles computed. Then, the percentiles from each year in both periods were ranked, the differences between the ranked data were computed, and Student's t-tests (Helsel and Hirsch, 1992) were done on the differences. The rank-sum tests indicate no statistically significant differences in the medians of any flow percentile; however, the p-values for discharges larger than the 83.3 percentile are all less than 0.20 - evidence for differences, but not strong enough evidence to declare the differences "significant." The tests on the differences in the ranked percentiles indicate that the daily discharges for the early and late periods are significantly different for the 75 percentile and larger flows. The p-values associated with these tests are summarized in table 4. Similar analyses were not done for the Hempstead streamflow-gaging station data because continuous daily discharge for the early period was not available; however, the distributions of daily flows are similar between the two sites.

The preceding analyses indicate that the magnitude of discharges with larger recurrence intervals (90 percentile and larger daily flows) has decreased since the early 1940s. The reduction in the upper tails of the distributions of the daily discharges are consistent with what would be expected downstream from major reservoirs (Collier and others, 1996). The larger dis- charges likely transport a large part of the Brazos River sand load.

Changes in transport capacity because of reductions in the frequency and magnitude of large discharges can be identified by estimating loads using the historical record of daily discharge and a functional relation between sand transport and discharge. This functional relation can be from a regression analysis relating measured transport rates with discharge, a sedimenttransport curve relating transport rates with discharge, or one of the many sediment-transport equations published in the literature.

A sediment-transport curve was drawn relating suspended-sand load to water discharge at the Richmond streamflow-gaging station (fig. 21) to test whether the capacity of the Brazos River to transport sediment has been reduced significantly solely because of reductions in large discharges. The sediment samples taken before 1982 and after 1981 were not differentiated because the intent was to determine, given a representative transport relation, whether reductions in the frequency and magnitude of large discharges could reduce the capacity of the Brazos River to transport sand-size sediment. Load-discharge pairs were read from the rating curve and used to build a rating table. The rating table was applied to the historical record of daily discharge at the Richmond streamflow-gaging station using log-log interpolation between the rating table values to compute daily values of suspended-sand load.

The daily values of suspended-sand load were then summed to annual values, as shown in figure 22 .

Table 4. Summary of statistical tests for differences in annually computed daily flow percentiles between the pre1940 period and the 1969-95 period at streamflow-gaging station 08114000 Brazos River at Richmond, Texas

\begin{tabular}{cccccc}
\hline & \multicolumn{2}{c}{$\begin{array}{c}\text { Median discharge } \\
\text { (cubic feet per second) }\end{array}$} & & \multicolumn{2}{c}{ p-value } \\
\cline { 2 - 3 } \cline { 5 - 6 } \cline { 5 - 6 } & Pre-1940 & $\mathbf{1 9 6 9 - 9 5}$ & & $\begin{array}{c}\text { Test for difference } \\
\text { in median percentile }\end{array}$ & $\begin{array}{c}\text { Test for difference } \\
\text { in ranked percentile }\end{array}$ \\
\hline 50 & 8,583 & 7,594 & & 0.450 & 0.332 \\
75 & 17,427 & 15,190 & & .265 & .013 \\
80 & 20,615 & 17,717 & & .241 & .039 \\
83.3 & 23,212 & 19,811 & & .210 & .039 \\
87.5 & 26,836 & 23,284 & & .176 & .013 \\
90 & 29,650 & 26,105 & & .151 & .004 \\
95 & 38,465 & 34,439 & & .145 & $<.001$ \\
98 & 49,870 & 43,290 & & .134 & $<.001$ \\
99 & 57,923 & 48,679 & & .129 & $<.001$ \\
\hline
\end{tabular}




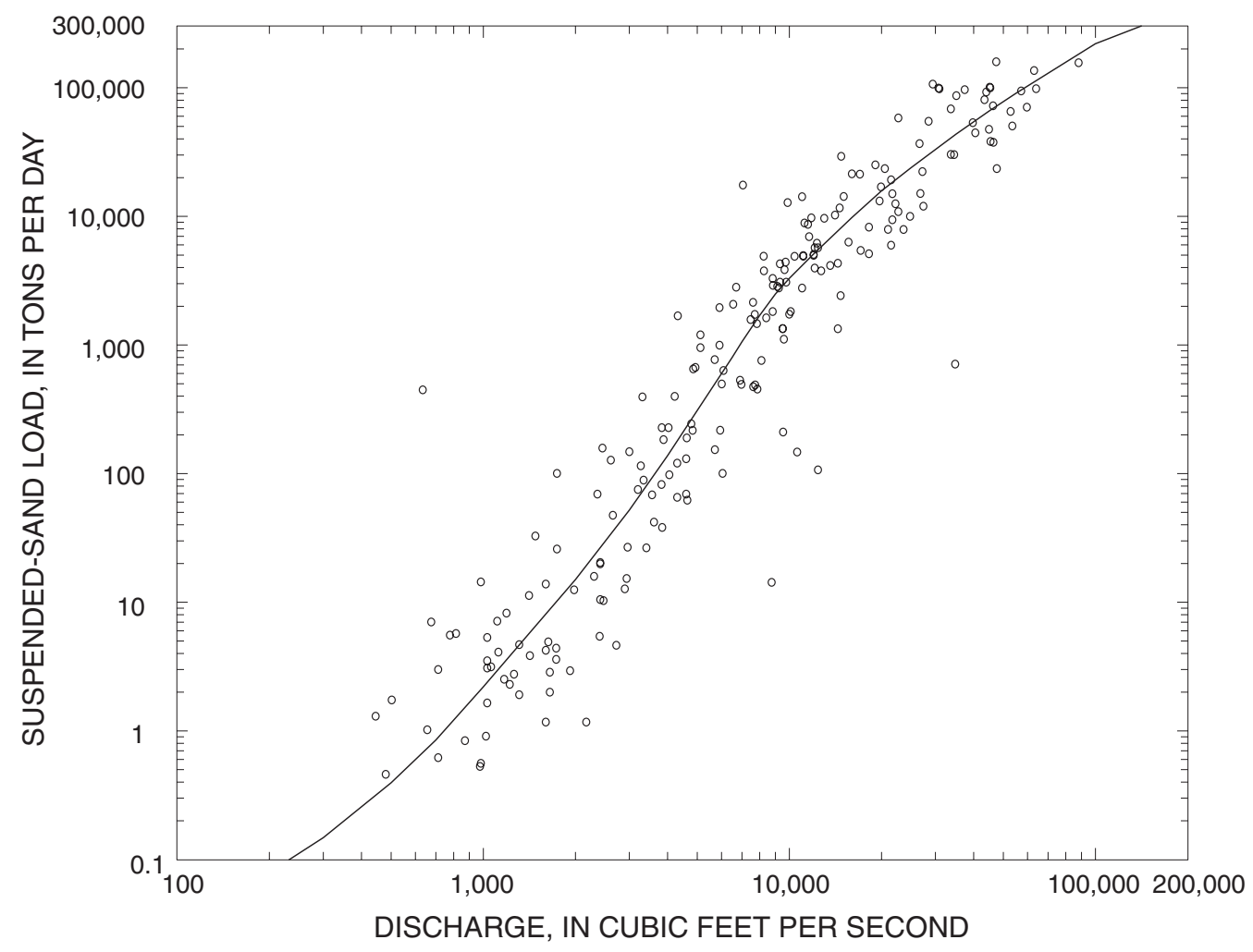

Figure 21. Suspended-sand transport curve for streamflow-gaging station 08114000 Brazos River at Richmond, Texas.

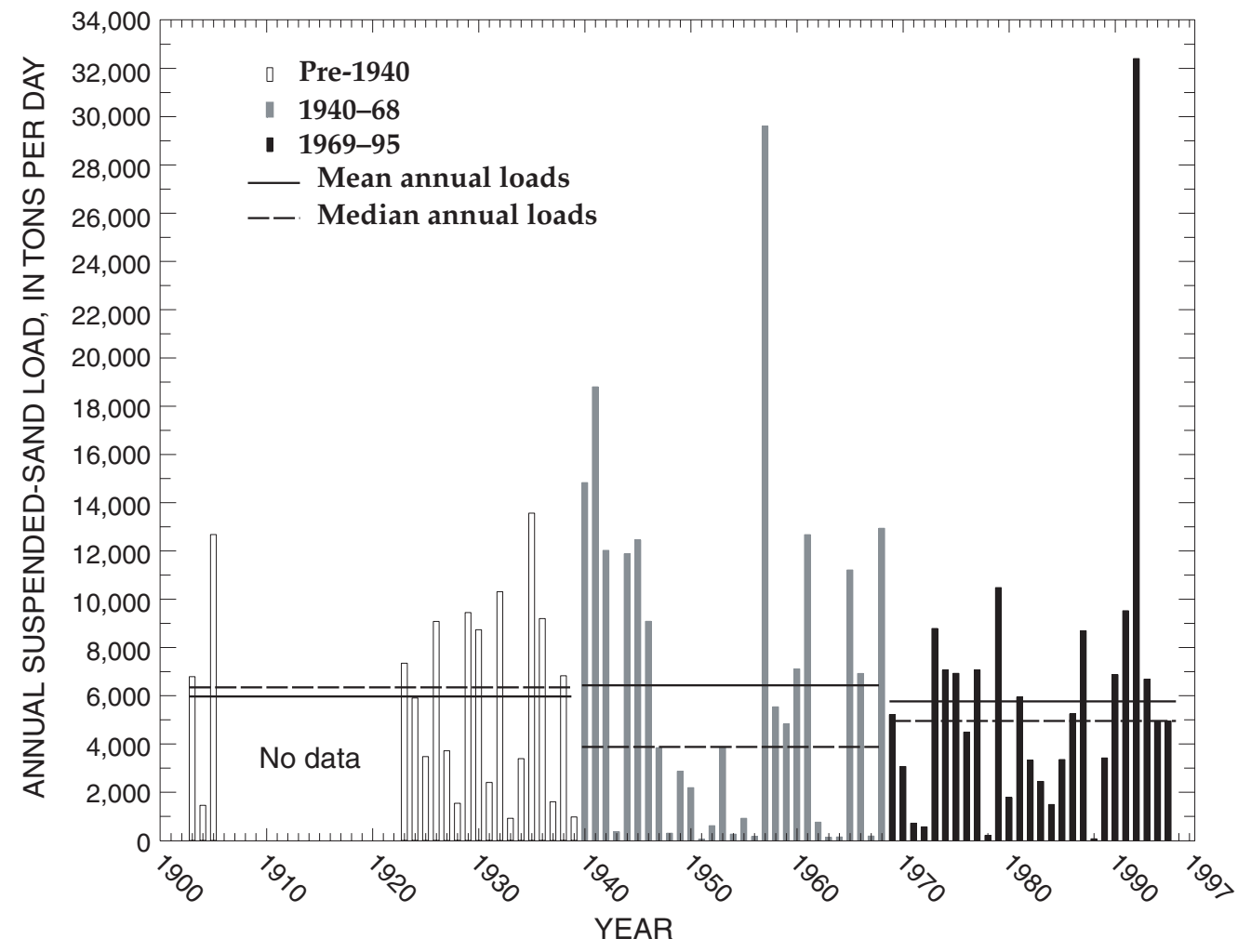

Figure 22. Annual suspended-sand loads at streamflow-gaging station 08114000 Brazos River at Richmond, Texas. 
There is no statistically significant difference in the median annual loads between the early, middle, and late periods. The median annual suspended-sand load was estimated to be 6,350 tons per day during the early period and 4,960 tons per day during the late period. Although the difference between the early and late periods seems appreciable, it is not statistically significant $(\mathrm{p}=0.22)$, probably because of the large variance in the data and the relatively few datapoints available. The fact that the median annual suspended-sand loads were not significantly different between the early and late periods prevents a definitive conclusion that the frequency and magnitude of large discharges reduced the capacity of the Brazos River to transport sand-size sediment.

\section{POTENTIAL SOURCES OF CHANGE IN SAND TRANSPORT}

Several indicators of change in the transport of sand in the Brazos River have been identified, and all relate within the context of Lane's relation (eq. 3). The Brazos River was shown to develop sufficient shear stress to mobilize its bed material at least 82 percent of the time, so the capacity of the river to transport bed material is not in question. The transport of sand in the Brazos River depends on a complex set of factors, most of which are continually changing. Identification of a single causative factor as the sole source of change generally is impossible, unless that activity overwhelmingly influences the hydrology of the basin or the hydraulic characteristics of the river channel. All of the indicators of change identified provide only subtle inferences of change. They do not provide definitive evidence of a change in sand loads, but they do imply that sand loads are decreasing somewhat. Below, several possible sources of change are discussed in relation to the indicators previously identified.

\section{Reservoir Construction}

The extensive reservoir construction in the Brazos River Basin could substantially reduce sand transport to the Gulf by trapping sediment and by reducing the magnitude of upper-tail discharges. The entrapment of sand generally has the most critical effect immediately downstream from a reservoir. Water released from the reservoir contains little or no sand and removes material from the stream channel to satisfy the transport capacity. Subsequent channel down-cutting as great as 30 or $40 \mathrm{ft}$ has been observed in some rivers. Channel erosion continues downstream until instream sediment is resupplied by erosion from the bed and banks of the channel or by tributaries.

The amount of sediment trapped in the Brazos River reservoirs is difficult to determine. Initial reservoir-capacity surveys made during the times when most reservoirs were constructed were of limited accuracy. Relatively few updated surveys have been made in the Brazos River Basin, and until recently, those surveys also had accuracy limitations. The TWDB recently began using improved reservoir-capacity survey techniques that have been used for a few reservoirs in the Brazos River Basin. The accuracy of the new surveys is greatly improved over those made using traditional methods. However, the increase in accuracy limits the ability to make meaningful comparisons between the new surveys and the original surveys to determine reservoir sedimentation rates. One cannot make a comparison between the two with any degree of confidence (Scott Sullivan, Texas Water Development Board, oral commun., 1996). Any change in reservoir capacity could be attributed simply to differences in survey techniques. Several of the recent reservoir-capacity surveys made by the TWDB have shown larger reservoir capacities than those obtained during the original surveys.

Regardless, reservoir entrapment of sand probably has little effect on sand transport to the lower reaches of the Brazos River. About 350 river miles separate the farthest downstream main-channel reservoir (Lake Whitney) and the Richmond streamflowgaging station. The City of Waco operates a watersupply diversion dam on the main stem of the Brazos River, about 309 river miles upstream of the Richmond gaging station, which also has the potential to trap sand. About 40 tributaries drain to the Brazos River between Lake Whitney and Waco. Childress Creek is the largest unregulated tributary between Lake Whitney and Waco, with a drainage area of $87 \mathrm{mi}^{2}$. Allen and others (1989) documented about 4 to $5 \mathrm{ft}$ of local channel agradation in this reach since construction of Lake Whitney in 1951 and stated that the reduction of peak flows from Lake Whitney reduced the ability of the Brazos River to transport sediment discharged from tributaries, 
facilitating the growth of tributary delta systems downstream of Lake Whitney. Bank loss in this reach has ranged from 5 to $14 \mathrm{ft} / \mathrm{yr}$, indicating that substantial quantities of sand are being introduced to the main channel. Apparently, sand trapped by the upstream reservoir is compensated for within a short distance downstream by the introduction of tributary sediment and localized bank erosion.

Reservoirs have reduced the magnitude of uppertail discharges in the lower Brazos River and reduced the capacity of the Brazos River to transport sand to the Gulf. However, during extended, severely dry periods such as occurred during the drought of the 1950s, regulated peak flows were smaller than natural peaks under drought conditions to maintain reservoir conservation storage. Seelig and Sorenson (1973) analyzed flows and sediment loads from the Brazos River to the Gulf from about 1930 to about 1965 . They identify a substantial decrease (about 60 percent) in the transport of sand to the Gulf beginning about 1941 and attribute much of the decrease to reservoir construction. However, data collected since 1965 indicate that sand transport has not decreased as much as reported by Seelig and Sorenson (1973). The decreases identified by Seelig and Sorenson (1973) likely were caused more by the extended drought of the 1950s than by upstream reservoir construction. However, the presence of the reservoirs during this severe drought did reduce peak flows and, consequently, sediment transport.

\section{Changes in Land Use}

Changes in land use in a river basin will alter the amount of sediment delivered to a stream by erosion processes. During the 19th and early parts of the 20th centuries, the amount of land in the Brazos River Basin under agricultural production increased substantially. This land, originally rangeland or forested woodland, was cleared of vegetation to grow crops such as cotton, corn, and sorghum. Modern soil-conservation practices in agriculture were not available, and the erosion potential of the cleared land greatly increased when the natural vegetation was removed. Although no records are available, it is recognized generally that substantial quantities of topsoil were lost. The topsoil was transported to the tributaries and main channel of the Brazos River by hillslope erosion processes.

Although accurate determination of the quantity of soil transported to the Brazos River attributable to agricultural practices is not possible, documented his- torical amounts of land under agricultural production can be used to estimate qualitatively the erosion potential in the watershed at various times. The U.S. Department of Agriculture publishes by county the number of acres harvested every 5 years. The county figures are aggregated by individual crop types. The data for 192492 were retrieved for total crops harvested and for total acres of hay for the 27 counties that are partly or completely within the lower one-third of the Brazos River Basin. The total area in these counties is about $15,000,000$ acres. Acres of hay were subtracted from the total acres harvested to estimate the amount of land under non-hay crop production. Land under production of non-hay crops generally has more erosion potential than land under hay production.

As shown in figure 23, the total area of harvested acres of non-hay crops in the lower basin during 1924 92 decreased from about 32 percent to about 8 percent of the total area. Without consideration of improved soil-conservation practices, the erosion potential in the Brazos River Basin has decreased substantially since 1924, simply on the basis of total acreage removed from agricultural production. Most of this land has been transformed to open rangeland for which the erosion potential is small. Substantial decreases in the erosion potential of a river basin generally are followed by a decrease in the quantity of sediment reaching the mainstem channel; the decrease generally is not immediate but will occur gradually as the supply from watershed erosion diminishes. Any decrease in the quantity of sediment transported by the Brazos River can be attributed partly to a decrease in the supply of sediment from the watershed, manifested first in a decrease in wash load, which tends to have a rapid response to changes in watershed erosion potential.

\section{Instream Sand and Gravel Mining}

Sand and gravel have been mined from the lower Brazos River channel for many years. The locations of sand and gravel mining operations, as permitted by the TPWD in 1995, in the reach between the Hempstead and Rosharon streamflow-gaging stations are shown in figure 24 . The operations in this area account for 2 to 3 percent of the total statewide sand and gravel production (Gustavson and Bullen, 1996).

Annual weight of sand extracted by the operators in the area as reported to the TPWD for 1979-95 is shown in figure 25. The total suspended sand transported past the 


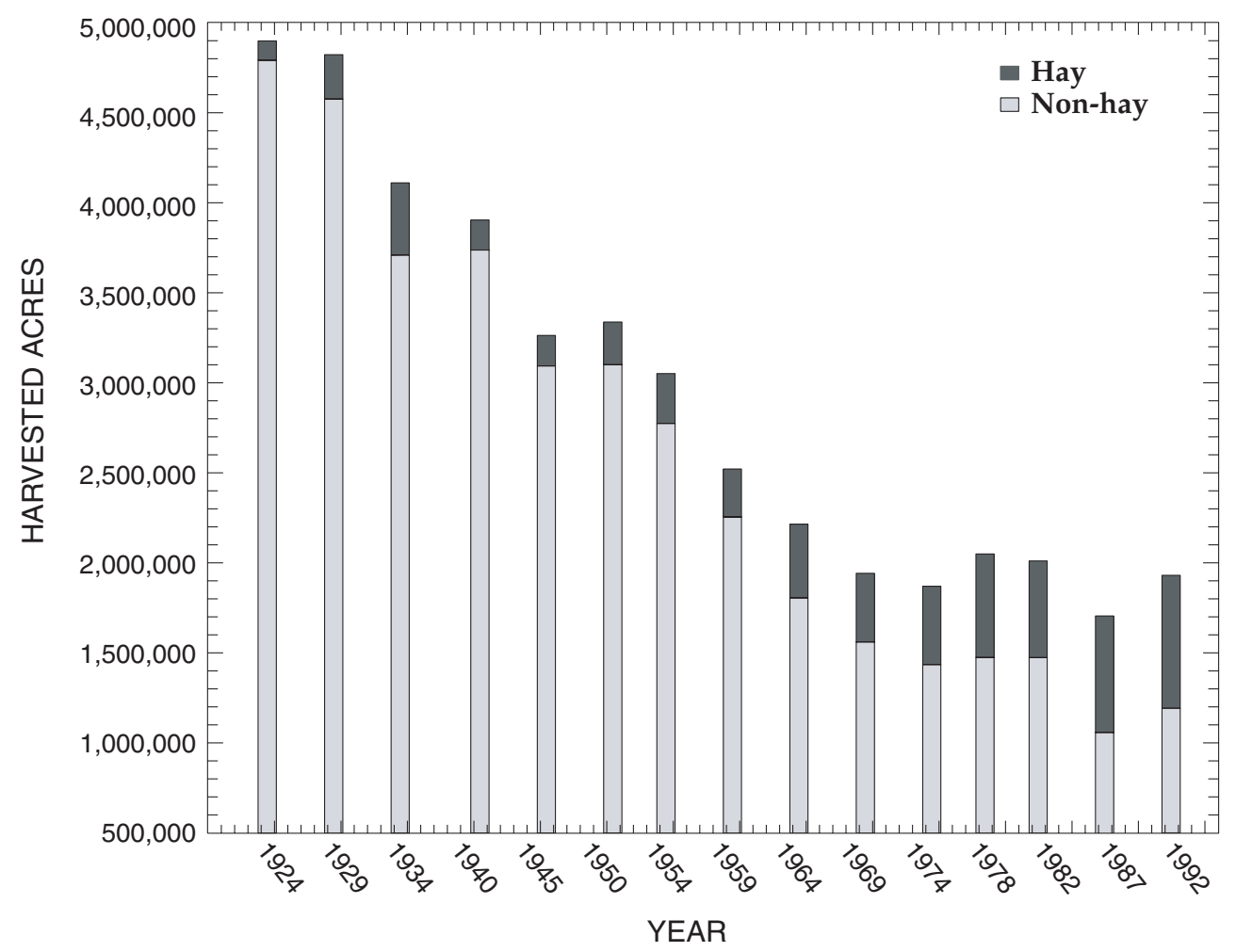

Figure 23. Total acres harvested in the 27 counties in the lower Brazos River Basin, Texas.

Richmond streamflow-gaging station computed using the sediment-transport curve described previously also is shown in figure 25 .

Cumulative weight of sand extracted and cumulative sand transported for 1979-95 are shown in figure 26. During that period, sand extracted from the Brazos River channel totaled about 28 percent of the suspended sand transported past the Richmond streamflow-gaging station. The amount of sand extracted through instream mining represents a fraction of the total sediment transported by the Brazos River.

Depending on the configuration and size of operation, the dredged (excavated) part of the main channel has the potential to refill rather quickly by trapping sediment transported from upstream. Most dredged areas can be substantially refilled during a single, prolonged rise of the Brazos River (David Kurz, Sand Supply Corp., oral commun., 1996). Bed load is trapped, and larger particles in suspension also can settle out when velocities in the dredged area generally are slower than those in the undisturbed channel immediately adjacent.

A sudden decrease in the supply of sediment (such as potentially would occur downstream from a mining operation that traps substantial quantities of sediment) could cause bank erosion and general channel instability downstream. In Lane's relation (eq. 3), a decrease in sediment supply, assuming no change in the dominant discharge or the characteristic size of the transported sediment, will result in a decrease in the energy slope. A decrease in the energy slope will result in either channel down-cutting, an increased rate of channel migration (meandering), or a combination of both.

Gustavson and Bullen (1996) investigated the wavelength and amplitude of meander bends in the Brazos River in the same area as this study and found no temporal changes in the general morphology of individual meander loops. They did find that the lateral migration of meander bends decreases through the study area and that the channel becomes progressively more incised in the downstream direction. However, Gustavson and Bullen (1996) attribute these findings more to variation in valley slope and lithology than to sand and gravel mining. 


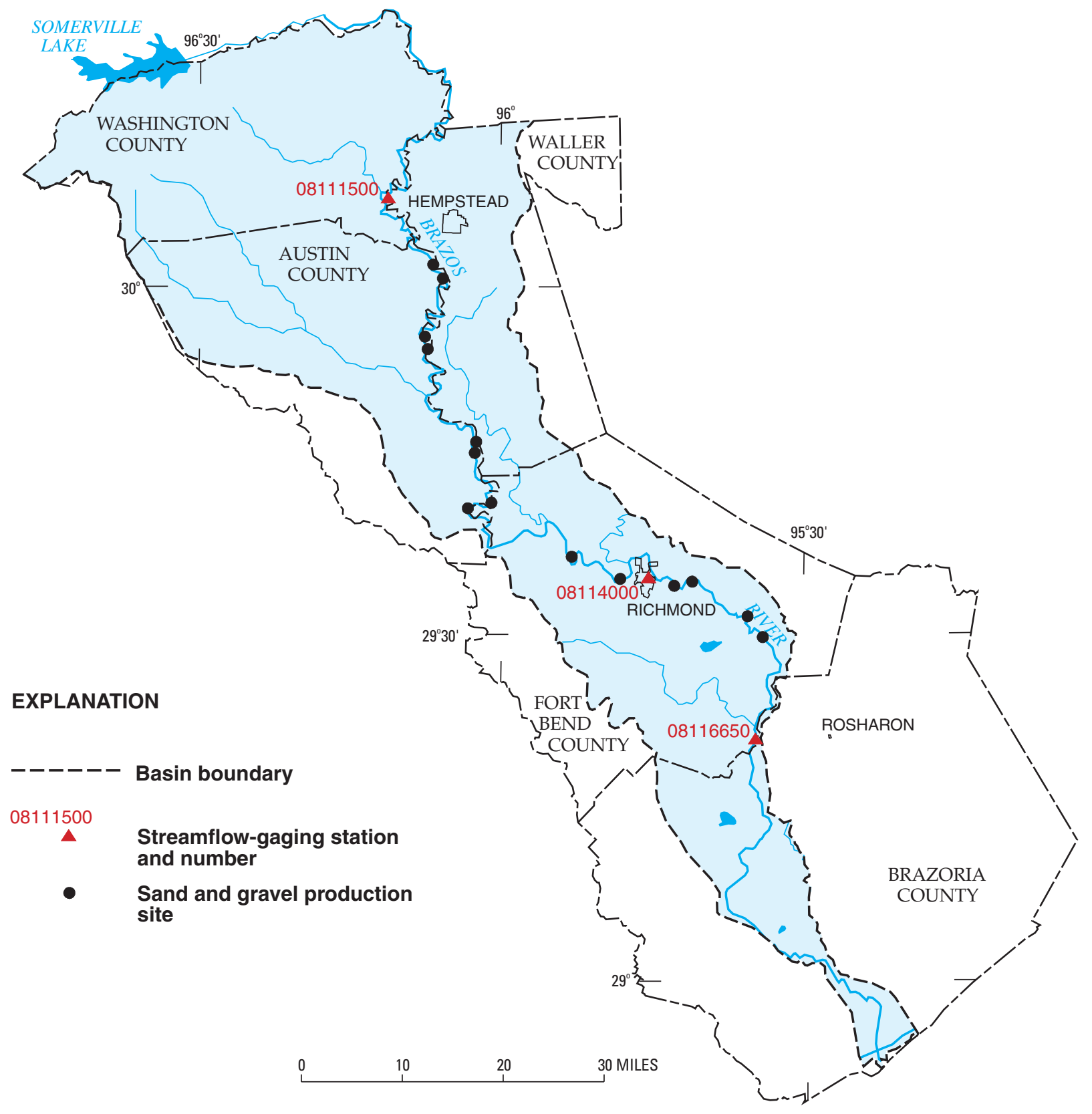

Figure 24. Location of selected sand and gravel production sites in the lower Brazos River Basin, Texas.

The quantity of sediment extracted by instream sand and gravel mining operations represents about 28 percent of the suspended sand transported by the Brazos River at Richmond. However, it represents a potentially smaller percentage of the total sand transported by the river in suspension and bed load. The bed load can range from 10 to 150 percent of the suspended load of a stream (Simons and Senturk, 1992). On the basis of these per- centages, the quantity of sand extracted from the Brazos River could represent from 11 to 25 percent of the total sand transported. This extraction occurs over a distance of about 100 river miles, which probably lessens the overall effects. Consequently, the overall long-term effects of instream sand and gravel mining on sand transported from the Brazos River to the Gulf of Mexico could not be quantified. 


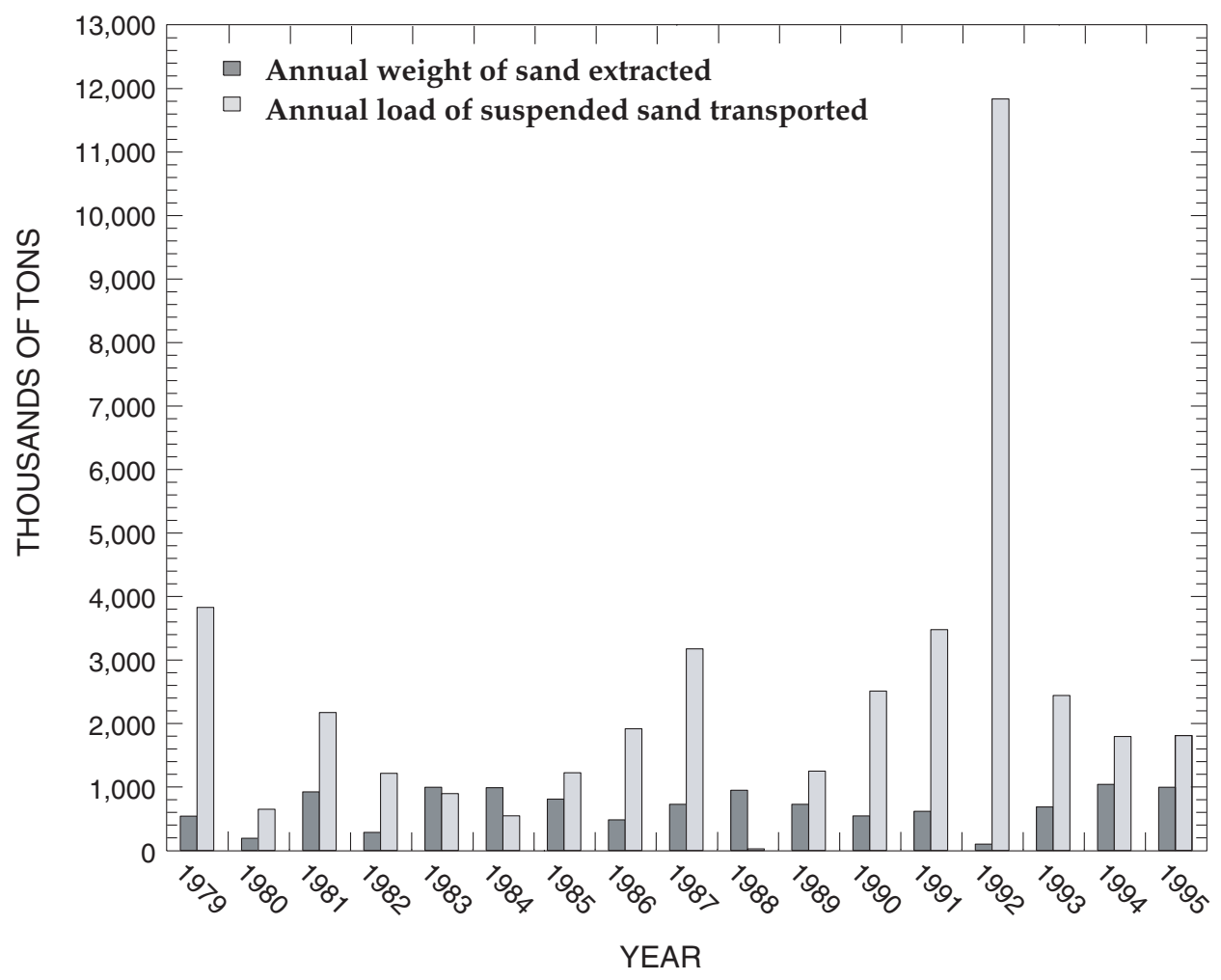

Figure 25. Total annual weight of sand extracted and annual loads of suspended sand transported in the Brazos River between Hempstead and Rosharon, Texas, 1979-95.

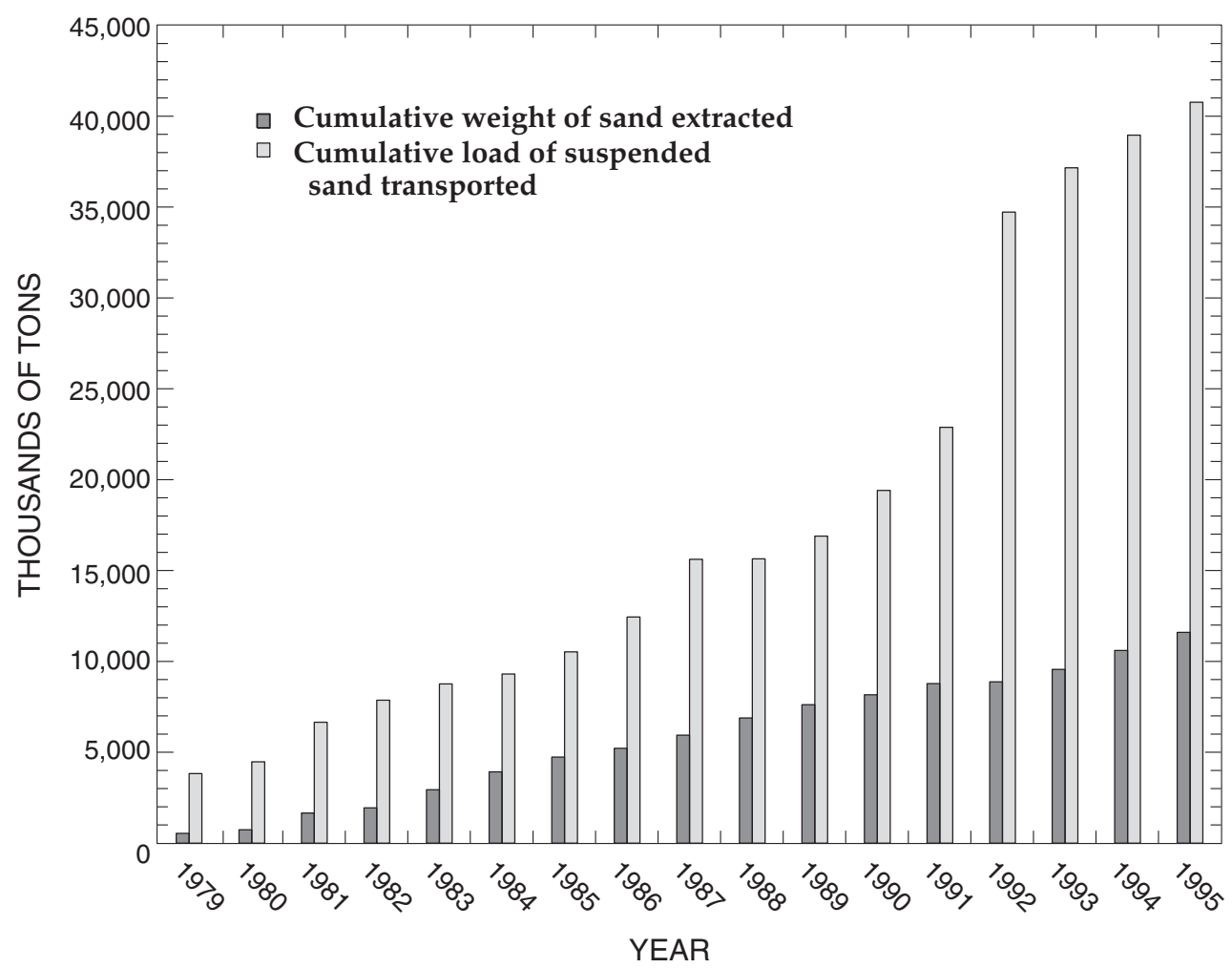

Figure 26. Cumulative annual weight of sand extracted and annual loads of suspended sand transported in the Brazos River between Hempstead and Rosharon, Texas, 1979-95. 


\section{SUMMARY}

The Brazos River can be characterized as an incised, meandering, sand-bed channel with unstable banks. Frequent, near-vertical cut banks 20 to $35 \mathrm{ft}$ high are prominent along much of its length. The channel slopes at about $0.7 \mathrm{ft} / \mathrm{mi}$ in the lower 300 river miles. Extensive reservoir construction has taken place in the Brazos River Basin since the early 1940s. The reservoir storage in the basin increased from 258,675 acre-ft in 1940 to 4,613,800 acre-ft in 1995. Land use in the Brazos River Basin predominantly is agricultural and open rangeland, with about 1,900,000 harvested acres in the 27 counties in the lower part of the basin (in 1992). The dominant crops produced in the basin are cotton, corn, and sorghum.

In a river, sediment is transported in suspension, as bed load by rolling and sliding along the bed, and conjunctively by suspension and bed load. This movement depends on the nature of the sediment (size, specific gravity, and shape) and the hydraulic characteristics of the flow. Generally, only larger discharges develop the hydraulic characteristics necessary to transport substantial quantities of sand-size sediment. The results of a tractive-force analysis at three sampled discharges for the $\mathrm{D}_{50}$ and $\mathrm{D}_{85}$ particle sizes indicate that each sampled discharge has adequate capacity to initiate motion of the bed material in the Brazos River.

The transport of sediment in most rivers is affected by multiple interdependent factors including land-use changes in the basin, natural erosion processes along the main stem and tributaries, basin hydrology (particularly extreme events), water-resource development, and human activity in the main channel. River morphology and sediment transport change continually as a river adjusts in response to changes in these and other factors. River channels will adjust to minimize energy dissipation, and these adjustments affect the capacity to transport the available sediment with the available discharge. Channel-adjustment processes can be characterized by Lane's relation: The product of river discharge and river slope are proportional to the product of the bed-sediment discharge and a characteristic particle-size diameter.

Changes in the capacity of a river to transport sand can be identified in the context of Lane's relation through changes in channel geometry, changes in the characteristics of suspended loads, and changes in discharge. On the basis of inspection and analysis of historical stage-discharge relations, the Brazos River channel has been undergoing continual adjustment since the 1940s. The expected water-surface altitude for a discharge of $5,000 \mathrm{ft}^{3} / \mathrm{s}$ has decreased about 2 to $4 \mathrm{ft}$ at the Hempstead and Richmond gaging stations since the early 1940s. These decreases in water-surface altitude indicate channel adjustments consistent with a decreased supply of sand-size sediment.

The amount of sand-size sediment in suspendedsediment samples at the Richmond streamflow-gaging station decreased between the periods 1969-81 and 1982-95. This decrease cannot be attributed to any change in sampling strategy; although the number of smaller discharges sampled each year did increase, no identifiable change was detected in the larger sampled discharges for which sand concentrations typically are larger. These changes occurred during a relatively short time period (1969-95) compared with the length of record for stage-discharge measurements and give no insight into overall changes since the early 1940s. The distribution of both daily and annual-peak discharges at the Hempstead and Richmond streamflow-gaging stations has changed. Discharges larger than the 90percentile daily flow and most annual-peak discharges have decreased. The reduction in the largest discharges would tend to reduce the capacity of the Brazos River to transport sand. However, the computed annual loads of suspended sand indicate no statistically significant change in the median annual load.

The transport of sand in the Brazos River depends on a complex set of factors, most of which are continually changing. Potential sources of change in sand transport in the Brazos River include the effects from reservoir construction, changes in land use, and instream sand and gravel mining. Extensive reservoir construction in the Brazos River Basin has reduced sand transport downstream from reservoirs by trapping sediment and by reducing the magnitude of peak discharges. The reservoir entrapment of sand probably has little effect on sand transport to the lower reaches of the Brazos River because bank losses in the downstream reaches indicate that substantial quantities of sand are being introduced to the main channel. The sand that is trapped by the upstream reservoir apparently is compensated for downstream by the introduction of tributary sediment and localized bank erosion.

Changes in land use in a river basin will alter the amount of sediment delivered to a stream by erosion processes. Substantial decreases in the erosion potential of a river basin generally are followed by a decrease in the quantity of sediment reaching the main-stem 
channel. The total area of harvested acres of non-hay crops in the lower Brazos River Basin during 1924-92 decreased more than 75 percent from about 32 percent to about 8 percent of the total area. The removal of major acreage from agricultural production has substantially reduced erosion potential.

Several sand and gravel mining sites are located on the Brazos River between Hempstead and Rosharon. The quantity of sediment extracted by instream sand and gravel mining operations could represent from 11 to 25 percent of the total sand transported by the Brazos River. However, the extraction occurs over a distance of about 100 river miles, which probably lessons the overall effects. The effects of mining on sand transport could not be quantified.

\section{REFERENCES CITED}

Allen, P.M., Hobbs, R., and Maier, N.D., 1989, Downstream impacts of a dam on a bedrock fluvial system, Brazos River, Central Texas: Bulletin of the Association of Engineering Geologists, v. XXVI, no. 2, p. 165-189.

Andrews, F.L., 1989, Monthly and annual suspendedsediment loads in the Brazos River at Richmond, Texas, 1966-86 water years: U.S. Geological Survey WaterResources Investigations Report 88-4216, 20 p.

Chang, H.H., 1988, Fluvial processes in river engineering: New York, John Wiley, 432 p.

Cleveland, W.S., 1979, Robust locally weighted regression and smoothing scatterplots: Journal of the American Statistical Association, v. 74, p. 829-836.

Colby, B.R., 1957, Relationship of unmeasured sediment discharge to mean velocity: American Geophysical Union Transactions, v. 35, no. 5, p. 708-717.

Collier, M., Webb, R.H., and Schmidt, J.C., 1996, Dams and reservoirs, a primer on the downstream effects of dams: U.S. Geological Survey Circular 1126, 94 p.

David, H.A., 1981, Order statistics: New York, John Wiley, $360 \mathrm{p}$.

Dougherty, J.P., 1979, Suspended-sediment load of Texas streams, compilation report, October 1971-September 1975: Texas Department of Water Resources Report 233, $83 \mathrm{p}$.

Edwards, T.K., and Glysson, G.D., 1999, Field methods for measurement of fluvial sediment: U.S. Geological Survey Techniques of Water-Resources Investigations, book 3, chap. C2, 89 p.

Gillespie, B.M., and Giardino, J.R., 1997, The nature of channel planform change-Brazos River, Texas: Texas Journal of Science, v. 49, no. 2, p. 108-142.

Gustavson, T.C., and Bullen, G.R., 1996, Sand and gravel mining in the Brazos River-An assessment of erosion potential and economic impact: University of Texas Bureau of Economic Geology, 28 p.

Guy, H.P., and Norman, V.W., 1970, Field methods for measurement of fluvial sediment: U.S. Geological Survey Techniques of Water-Resources Investigations, book 3, chap. C2, 59 p.

Helsel, D.R., and Hirsch, R.M., 1992, Studies in environmental science 49-Statistical methods in water resources: New York, Elsevier, 522 p.

Kaigh, W.D., and Driscoll, M.F., 1987, Numerical and graphical data summary using o-statistics: The American Statistician, v. 41, no. 1, p. 25-32.

Lane, E.W., 1955, The importance of fluvial geomorphology in hydraulic engineering: American Society of Civil Engineers Proceedings, v. 81, no. 745, p. 1-17.

Mathewson, C.C., and Minter, L.L., 1976, Impact of water resource development on coastal erosion, Brazos River, Texas: Texas Water Resources Institute, Texas A\&M University, Technical Report 77, 85 p.

McGowen, J.H., Garner, L.E., and Wilkinson, B.H., 1977, The Gulf Shoreline of Texas-Processes, characteristics, and factors of use: University of Texas Bureau of Economic Geology, Geological Circular 77-3, 27 p.

Morton, R.A., and Pieper, M.J., 1975, Shoreline changes in the vicinity of the Brazos River Delta (San Luis Pass to Brown Cedar Cut), an analysis of historical changes of the Texas Gulf Shoreline: University of Texas Bureau of Economic Geology, Geological Circular 75-4, 47 p.

Richardson, E.V., Simons, D.B., and Julien, P.Y., 1990, Highways in the river environment: Participant Notebook, Federal Highway Administration, Publication FHWA-HI-90-016.

Robbins, C.H., and Simon, A., 1983, Man-induced channel adjustment in Tennessee streams: U.S. Geological Survey Open-File Report 83-043, 95 p.

Seelig, W.N., and Sorenson, R.M., 1973, Investigation of shoreline changes at Sargent Beach, Texas: Texas A\&M University, C.O.E. Report 169, 153 p.

Simons, D.B., and Senturk, F., 1992, Sediment transport technology, water and sediment dynamics: Littleton, Colo., Water Resources Publications, 897 p.

Stauble, D.K., Hubertz, J.M., Hoban, R.J., Livingston, C.R., Pollock, C.E., and Levine, D.R., 1994, Coastal studies in support of the Sargent Beach, Texas, erosion control project: Coastal Engineering Research Center, U.S. Army Corps of Engineers Waterways Experiment Station, Miscellaneous Paper CERC-94-3, 94 p.

Stelczer, K., 1981, Bed-load transport, theory and transport: Littleton, Colo., Water Resources Publications, 295 p.

Thornes, J.B., 1977, Hydraulic geometry and channel changes, in Gregory, K.J., ed., River channel changes: New York, John Wiley, p. 91-100. 
U.S. Department of Agriculture, 1997, Texas' 1992 census of agriculture state and county highlights: National Agricultural Statistics Service, accessed November 27, 2000, at URL

http://www.nass.usda.gov:80/census/census92/atlas92/ html/tx.htm

Vanoni, V.A., ed., 1975, Sedimentation engineeringManuals and reports on engineering practice, no. 54:

New York, American Society of Civil Engineers, 745 p.
Welborn, C.T., 1967, Comparative results of sediment sampling with the Texas sampler and the depth-integrating samplers: Texas Water Development Board Report 36, $109 \mathrm{p}$.

Wurbs, R.A., Bergman, C.E., Carriere, P.E., and Walls, B.W., 1988, Hydrologic and institutional water availability in the Brazos River Basin: Texas Water Resources Institute, Texas A\&M University, Technical Report 144, 238 p. 
District Chief

U.S. Geological Survey

8027 Exchange Dr.

Austin, TX 78754-4733 